\title{
Aerosol distribution in the northern Gulf of Guinea: local anthropogenic sources, long-range transport, and the role of coastal shallow circulations
}

\author{
Cyrille Flamant $^{1}$, Adrien Deroubaix ${ }^{1,2}$, Patrick Chazette ${ }^{3}$, Joel Brito ${ }^{4}$, Marco Gaetani ${ }^{1}$, Peter Knippertz ${ }^{5}$, \\ Andreas H. Fink ${ }^{5}$, Gaëlle de Coetlogon ${ }^{1}$, Laurent Menut ${ }^{2}$, Aurélie Colomb ${ }^{4}$, Cyrielle Denjean ${ }^{6}$, Rémi Meynadier ${ }^{1}$, \\ Philip Rosenberg $^{7}$, Regis Dupuy ${ }^{4}$, Pamela Dominutti ${ }^{4}$, Jonathan Duplissy ${ }^{8}$, Thierry Bourrianne ${ }^{6}$, \\ Alfons Schwarzenboeck ${ }^{4}$, Michel Ramonet ${ }^{3}$, and Julien Totems ${ }^{3}$ \\ ${ }^{1}$ Laboratoire Atmosphères Milieux Observations Spatiales, Sorbonne Université, \\ Université Paris-Saclay and CNRS, Paris, France \\ ${ }^{2}$ Laboratoire de Météorologie Dynamique, Ecole Polytechnique, IPSL Research University, Ecole Normale Supérieure, \\ Université Paris-Saclay, Sorbonne Université, CNRS, Palaiseau, France \\ ${ }^{3}$ Laboratoire des Sciences du Climat et de l'Environnement, CEA, CNRS, Université Paris-Saclay, Gif-sur-Yvette, France \\ ${ }^{4}$ Laboratoire de Météorologie Physique, Université Clermont Auvergne, CNRS, Clermont-Ferrand, France \\ ${ }^{5}$ Institute of Meteorology and Climate Research, Karlsruhe Institute of Technology, Karlsruhe, Germany \\ ${ }^{6}$ Centre National de Recherches Météorologiques, Météo-France and CNRS, Toulouse, France \\ ${ }^{7}$ Institute of Climate and Atmospheric Science, School of Earth and Environment, University of Leeds, Leeds, UK \\ ${ }^{8}$ Helsinki Institute of Physics, University of Helsinki, Helsinki, Finland
}

Correspondence: Cyrille Flamant (cyrille.flamant@latmos.ipsl.fr)

Received: 31 March 2018 - Discussion started: 17 April 2018

Revised: 8 August 2018 - Accepted: 11 August 2018 - Published: 27 August 2018

\begin{abstract}
The complex vertical distribution of aerosols over coastal southern West Africa (SWA) is investigated using airborne observations and numerical simulations. Observations were gathered on 2 July 2016 offshore of Ghana and Togo, during the field phase of the Dynamics-Aerosol-ChemistryCloud Interactions in West Africa project. This was the only flight conducted over the ocean during which a downwardlooking lidar was operational. The aerosol loading in the lower troposphere includes emissions from coastal cities (Accra, Lomé, Cotonou, and Lagos) as well as biomass burning aerosol and dust associated with long-range transport from central Africa and the Sahara, respectively. Our results indicate that the aerosol distribution on this day is impacted by subsidence associated with zonal and meridional regionalscale overturning circulations associated with the land-sea surface temperature contrast and orography over Ghana and Togo, as typically observed on hot, cloud-free summer days such as 2 July 2016. Furthermore, we show that the zonal circulation evidenced on 2 July is a persistent feature over the Gulf of Guinea during July 2016. Numerical tracer re-
\end{abstract}

lease experiments highlight the dominance of aged emissions from Accra on the observed pollution plume loadings over the ocean, in the area of aircraft operation. The contribution of aged emission from Lomé and Cotonou is also evident above the marine boundary layer. Given the general direction of the monsoon flow, the tracer experiments indicate no contribution from Lagos emissions to the atmospheric composition of the area west of Cotonou, where our airborne observations were gathered. The tracer plume does not extend very far south over the ocean (i.e. less than $100 \mathrm{~km}$ from Accra), mostly because emissions are transported northeastward near the surface over land and westward above the marine atmospheric boundary layer. The latter is possible due to interactions between the monsoon flow, complex terrain, and land-sea breeze systems, which support the vertical mixing of the urban pollution. This work sheds light on the complex - and to date undocumented - mechanisms by which coastal shallow circulations can distribute atmospheric pollutants over the densely populated SWA region. 


\section{Introduction}

Aerosol-cloud-climate interactions play a fundamental role in radiative balance and energy redistribution in the tropics. Aerosol particles from natural and anthropogenic origins can serve as cloud condensation nuclei (Haywood and Boucher, 2000; Carslaw et al., 2010) and interact with solar and terrestrial radiation through absorption and scattering.

The atmosphere over southern West Africa (SWA) is a complex mix of local emissions (vegetation, traffic, domestic and waste fires, power plants, oil and gas rigs, ships) and remote sources (dust from the north and wild-fire related biomass burning aerosols from central Africa) (Knippertz et al., 2015a; Brito et al., 2018). In order to enhance our understanding of aerosol-cloud-climate interactions in SWA, it is of paramount importance to better characterize the composition and vertical distribution of the aerosol load over the eastern tropical Atlantic. This is particularly vital, since SWA is currently experiencing major economic and population growths (Liousse et al., 2014), and is projected to host several megacities (cities with over 10 million inhabitants) by the middle of the 21 st century (World Urbanization Prospect, 2015). This will likely boost anthropogenic emissions to unprecedented levels and imply profound impacts on population health (Lelieveld et al., 2015), on the radiative budget over SWA, and also on the West African Monsoon (WAM) system (Knippertz et al., 2015b). This will also add to the dust and biomass burning aerosol related perturbations already evidenced for the precipitation in the area (e.g. Huang et al., 2009). Likewise, urban pollution may also affect surface-atmosphere interactions and associated lower tropospheric dynamics over SWA such as for instance dust over the tropical Atlantic (e.g. Evan et al., 2009) or biomass burning aerosols over Amazonia (Zhang et al., 2008, 2009).

One of the aims of EU-funded project Dynamics-AerosolChemistry-Cloud Interactions in West Africa (DACCIWA, Knippertz et al., 2015b) is to understand the influence of atmospheric dynamics on the spatial distribution of both anthropogenic and natural aerosols over SWA after emission. One particularly important aspect is the fate of anthropogenic aerosols emitted at the coast as they are being transported away from the source. In addition, DACCIWA aims at assessing the impact of this complex atmospheric composition on the health of humans and ecosystems.

Urban aerosols are mostly transported with the southwesterly monsoon flow below $700 \mathrm{hPa}$ (e.g. Deroubaix et al., 2018). They may also reach the nearby ocean as the result of complex dynamical interactions between the monsoon flow, the northeasterly flow from the Sahel above, and the interactions with the atmospheric boundary layer (ABL) over the continent coupling the two layers when it is fully developed during daytime. This is because, as opposed to the marine ABL, the continental ABL exhibits a strong diurnal cycle (e.g. Parker et al., 2005; Lothon et al., 2008; Kalthoff et al., 2018). On hot, cloud-free summer days, land-sea breeze systems can develop at the coast (in conditions of moderate background monsoon flow, Parker et al., 2017), which contribute to the transport of pollutants emitted along the urbanized coastal strip of SWA.

The main objective of the present study is to understand how shallow overturning circulations developing in the lower troposphere over SWA on hot, cloud-free days can shape the urban pollution plumes emitted from coastal cities such as Accra, Lomé, Cotonou, and Lagos, both over the Gulf of Guinea and inland. Here, we take advantage of the airborne measurements acquired during the DACCIWA field campaign (June-July 2016, Flamant et al., 2018) as part of the European Facility for Airborne Research (EUFAR) funded Observing the Low-level Atmospheric Circulation in the Tropical Atlantic (OLACTA) project to assess the characteristics of different aerosol layers observed over the Gulf of Guinea. To study the role of atmospheric dynamics in aerosol spatial distribution, we use a unique combination of airborne observations from 2 July 2016, space-borne observations, and finally high-resolution simulations performed using the Weather and Research Forecast (WRF) and CHIMERE models. We show that the aerosol distribution on this day is impacted by subsidence associated with zonal and meridional regional-scale overturning circulations linked with land-sea surface temperature contrast and orography over Ghana and Togo, and that the zonal circulation evidenced on 2 July is a persistent feature over the Gulf of Guinea during July 2016. The flight made on the afternoon of 2 July is unique in the sense that it is the only flight conducted over the ocean during which a downward-looking lidar was operational. The combination of remote sensing to monitor the aerosol landscape over the Gulf of Guinea and in situ measurements to assess the nature of the observed aerosols was only possible on that day. Therefore, one should keep in mind that we are detailing a few mechanisms possibly responsible for shaping the aerosol composition over the Gulf of Guinea, and caution should be exercised when drawing more general conclusions regarding the role of the observed circulation in the aerosol redistribution in this region.

The airborne and space-borne data used in this paper are presented in Sect. 2, whereas the simulations are detailed in Sect. 3. Section 4 presents the synoptic situation and airborne operations over SWA on 2 July 2016. Atmospheric composition over the Gulf of Guinea as observed from aircraft in situ and remote sensing data is discussed in Sect. 5. Insights into the distribution of anthropogenic aerosols from tracer experiments are presented in Sect. 6 and long-range transport of aerosols related to regional-scale dynamics is described in Sect. 7. The influence of lower-tropospheric overturning circulations induced by the land-sea surface temperature gradient on the vertical distribution of aerosols over SWA is discussed in Sect. 8. In Sect. 9, we summarize and conclude. 


\section{Data}

\subsection{Airborne observations}

During the DACCIWA field campaign, airborne operations on the afternoon of 2 July 2016 were conducted with the ATR 42 of the Service des Avions Français Instrumentés pour la Recherche en Environnement (SAFIRE) over the Gulf of Guinea (Fig. 1). The afternoon flight was carried out in the framework of the EUFAR OLACTA project (Flamant et al., 2018). The aircraft was equipped with in situ dynamical and thermodynamical probes (yielding mean and turbulent variables), as well as in situ aerosol and cloud probes, and gasphase chemistry instruments. It also carried several radiometers (upward- and downward-looking pyranometers and pyrgeometers) as well as the Ultraviolet Lidar for Canopy Experiment (ULICE, Shang and Chazette, 2014). Table 1 summarizes the instruments used in this study (see the Supplement of Flamant et al., 2018, for the complete ATR 42 payload during the field campaign).

\subsubsection{ULICE observations}

The ULICE system was specifically designed to monitor the aerosol distribution in the lower troposphere. During the DACCIWA field campaign, ULICE was pointing to the nadir. The system's nominal temporal and along-line-of-sight resolutions are $100 \mathrm{~Hz}$ and $15 \mathrm{~m}$, respectively. In the present study, we use lidar-derived profiles of aerosol-related properties averaged over 1000 laser shots ( $\sim 10$ s sampling).

The ULICE receiver implements two channels for the detection of the elastic backscatter from the atmosphere in the parallel and perpendicular polarization planes relative to the linear polarization of the emitted light. The design and the calculations to retrieve the depolarization properties are explained in Chazette et al. (2012). Using co- and crosspolarization channels, the lidar allows identification of nonspherical particles in the atmosphere such as dust. The overlap factor is nearly identical for the two polarized channels, thereby permitting the assessment of the volume depolarization ratio (VDR) very close to the aircraft $(\sim 150 \mathrm{~m})$.

Lidar-derived extinction coefficient profiles (as well as other optical properties) are generally retrieved from socalled inversion procedures as abundantly described in the literature (e.g. Chazette et al., 2012). During the DACCIWA field campaign the lack of adequate observations did not allow us to perform proper retrievals of aerosol optical properties using such procedures. Hence, in the following we only use the apparent scattering ratio (ASR, the ratio of the total apparent backscatter coefficient to the molecular apparent backscatter coefficient denoted as $R_{\text {app }}$ ) and the VDR. Details are given in Appendix A, together with the characteristics of the lidar system.

Generally speaking, the VDR values observed during the flight are not very high and absolute values may be sub-
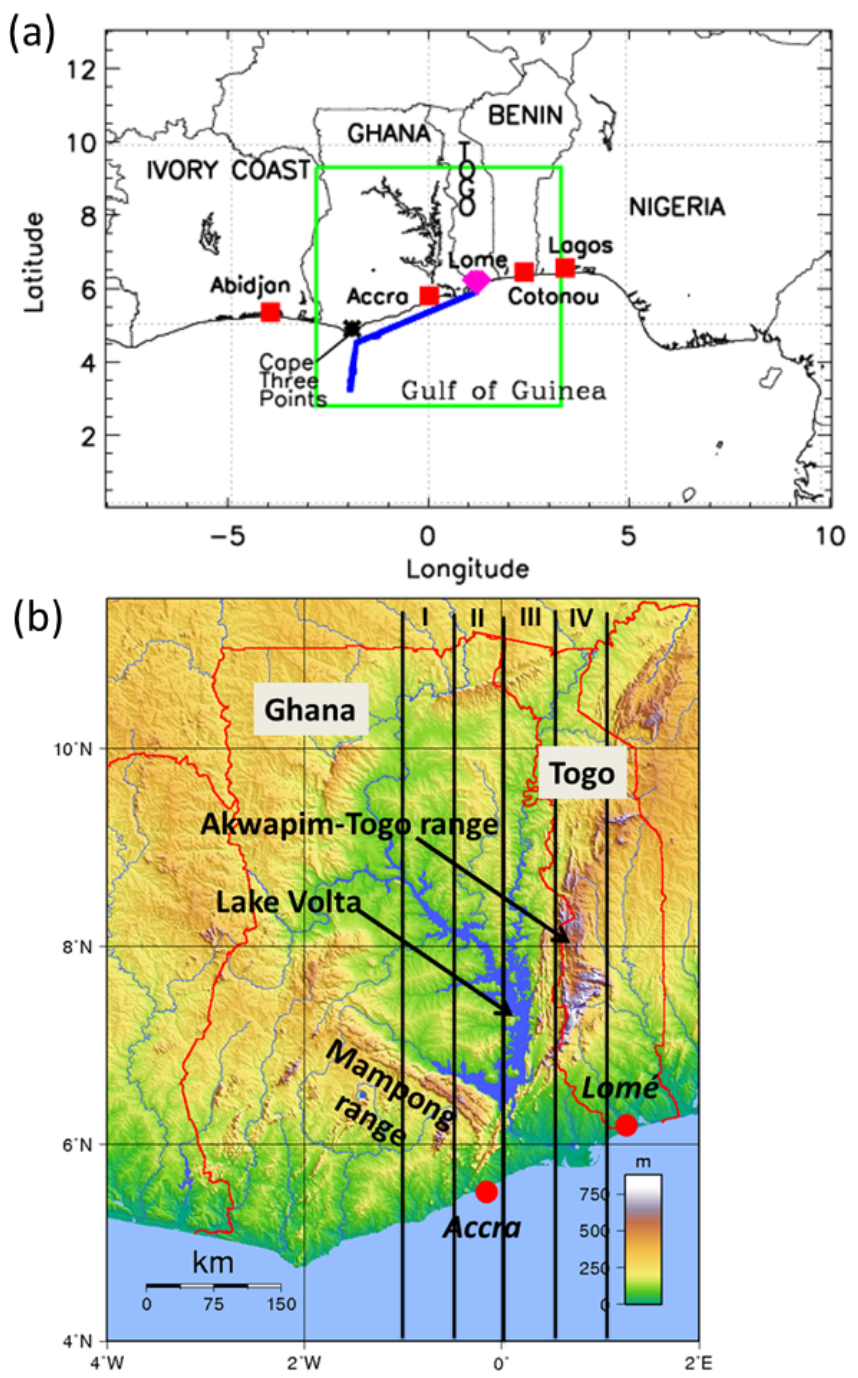

Figure 1. (a) Map of southern West Africa with the location of the main landmarks (e.g. cities, countries). The thick blue line represents the ATR 42 flight track on the afternoon of 2 July 2016. The red filled square symbols represent DACCIWA radiosounding stations used in this study. The pink filled circle represents the base of operation for aircraft during the DACCIWA field campaign. The green thick box represents the domain of the $2 \mathrm{~km}$ WRF simulation. (b) Topographic map of Ghana and Togo showing the main features of interest for this study as well as the transects along which tracer simulations are shown in Fig. 8. The transects are centered at $0.75^{\circ} \mathrm{W}, 0.25^{\circ} \mathrm{W}, 0.25^{\circ} \mathrm{E}$, and $0.75^{\circ} \mathrm{E}$ (for I, II, III, and IV, respectively) and are $0.5^{\circ}$ wide.

ject to biases. Nevertheless, relative fluctuations of VDR are accurately measured and useful as indicators of changes in aerosol properties.

\subsubsection{Aerosol- and gas-phase chemistry measurements}

For this study, we focus on available observations that can provide insights into the origin of the aerosol distribution 
Table 1. SAFIRE ATR 42 payload. Only instruments used in this study are listed. The complete payload is detailed in the Supplement of Flamant et al. (2018).

\begin{tabular}{|c|c|c|}
\hline Instrument & Parameter & Responsible institution \\
\hline $\begin{array}{l}P \text { (static \& dynamic): Rosemount } 120 \text { and } \\
1221\end{array}$ & $\begin{array}{l}\text { Pressure } \\
1 \mathrm{~s} \text { time resolution }\end{array}$ & SAFIRE/CNRS \\
\hline INS + GPS inertial units & $\begin{array}{l}\text { Wind component, position } \\
1 \mathrm{~s} \text { time resolution }\end{array}$ & SAFIRE/CNRS \\
\hline $\begin{array}{l}\text { Adjustable (flow, orientation) Aerosol } \\
\text { Community Inlet }\end{array}$ & $\begin{array}{l}\text { Particle aerosol sampling } \\
D_{50}=5 \mu \mathrm{m}\end{array}$ & CNRM/CNRS \\
\hline Aircraft DUAL CPC counter MARIE & $\begin{array}{l}\text { Particle number concentrations } \\
D>4 \mathrm{~nm} \& D>15 \mathrm{~nm} \text { (variable) } \\
1 \mathrm{~s} \text { time resolution } \\
\text { Uncertainty: } 10 \%\end{array}$ & LaMP/UBP \\
\hline OPC Grimm 1.109 & $\begin{array}{l}\text { Ambient particle size distribution } \\
0.25-25 \mu \mathrm{m} \\
6 \mathrm{~s} \text { time resolution }\end{array}$ & CNRM/CNRS \\
\hline $\operatorname{PSAP}(3 \lambda)$ & $\begin{array}{l}\text { Absorption coefficient, black carbon content } \\
\text { Blue } 476 \mathrm{~nm} \text {, green } 530 \mathrm{~nm} \text {, red } 660 \mathrm{~nm} \\
\text { 10 s time resolution } \\
\text { Uncertainty: } 30 \%\end{array}$ & LaMP/UPB \\
\hline CAPS-PMex & $\begin{array}{l}\text { Extinction } \mathrm{Mm}^{-1} \text { at } 530 \mathrm{~nm} \\
1 \mathrm{~s} \text { time resolution } \\
\text { Uncertainty: } 3 \%\end{array}$ & CNRM/CNRS \\
\hline TEI 49i & $\begin{array}{l}\mathrm{O}_{3} \\
20 \mathrm{~s} \text { time resolution } \\
\text { Precision: } 1 \text { ppbv }\end{array}$ & SAFIRE/CNRS \\
\hline TEI 42CTL $\mathrm{NO}_{x}$ analyser & $\begin{array}{l}\mathrm{NO}_{x} \\
8 \mathrm{~s} \text { time resolution } \\
\text { Precision: } 50 \mathrm{ppt} \text { integration over } 120 \mathrm{~s}\end{array}$ & SAFIRE/CNRS \\
\hline PICARRO & $\begin{array}{l}\text { CO cavity ring-down spectroscopy } \\
5 \mathrm{~s} \text { time resolution } \\
\text { Precision: } 30 \mathrm{ppb}\end{array}$ & SAFIRE/CNRS \\
\hline ULICE aerosol/cloud lidar & $\begin{array}{l}\text { Aerosol backscatter @ } 355 \mathrm{~nm} \\
\text { Resolution: } 15 \mathrm{~m} \text { on the vertical, averaged over } 10 \mathrm{~s} \\
\text { (1000 shots) on the horizontal. }\end{array}$ & LSCE/UPMC \\
\hline
\end{tabular}

over coastal SWA, namely biomass burning aerosols, dust, and urban pollution. Because of the complex atmospheric dynamics in the area, we cannot assume that only homogeneous air masses will be sampled with the aircraft. Rather, the selected observations are indicators of which type of aerosol dominates the composition of a given sampled air mass.

- Biomass burning aerosols: identification was conducted at times of enhanced ozone $\left(\mathrm{O}_{3}\right)$ and carbon monoxide (CO) mixing ratios as well as aerosol parameters such as light absorption/extinction and number concentration.

- Urban pollution: the main tracers used were CO, nitrogen oxide $\left(\mathrm{NO}_{x}\right)$, and total $(>10 \mathrm{~nm})$ particle number concentrations.
- Terrigenous aerosols (dust): layers were identified at times of enhanced aerosol parameters (particularly super-micron aerosols), in complement to the lidarderived VDR observations and not followed by $\mathrm{CO}$ or $\mathrm{O}_{3}$ enhancements (mostly associated with biomass burning here).

Sea salt cannot formally be identified with the in situ measurements conducted with the ATR 42 payload during DACCIWA. Gas-phase and aerosol metrics above are typically insensitive to relative humidity. The aerosol sampling lines are heated (to $35-40^{\circ} \mathrm{C}$ ), effectively limiting water uptake and relative humidity to values below $40 \%$. The $\mathrm{O}_{3}$ measurements in the ATR are based on dual-cell technology, and 
are therefore largely insensitive to ambient relative humidity according to Spicer et al. (2010), in spite of the humid environmental conditions over the Gulf of Guinea.

In addition, absorption Angstrom exponent (AAE) measurements are used to distinguish urban air pollution from biomass burning smoke (Clarke et al., 2007) and mineral dust (Collaud Coen et al., 2004). In general the AAE values for carbonaceous particles are $\sim 1$ for urban pollution, between 1.5 and 2 for biomass smoke, and around 3 for dust (Bergstrom et al., 2007). AAE values are rather insensitive to the size distribution of sampled aerosols. Therefore, even though aerosol measurements may be affected by the inlet efficiency, the derived AAE will still be a good indicator for discriminating plumes dominated by dust, biomass burning, and urban aerosols (e.g. Kirchstetter et al., 2004; Bergstrom et al., 2007; Toledano et al., 2007; Russell et al., 2010).

The Particle Soot Absorption Photometer (PSAP, model PSAP3L) measures the aerosol optical absorption coefficient at three wavelengths $(467,530$, and $660 \mathrm{~nm})$ with a sampling time of $10 \mathrm{~s}$. The data were corrected for multiple scattering and shadowing effects according to Bond et al. (1999) and Müller et al. (2009). Data with a filter transmission under 0.7 are removed as corrections are not applicable. Furthermore, PSAP measurements were used to compute the AAE. The particle extinction coefficient is measured with a cavity attenuated phase shift particle light extinction monitor (CAPSPMex, Aerodyne Research) operated at the wavelength of $530 \mathrm{~nm}$. Data were processed with a time resolution of $1 \mathrm{~s}$. An integrated nephelometer (Ecotech, model Aurora 3000) provided aerosol light scattering at three wavelengths (450, 550 , and $700 \mathrm{~nm}$ ), which was used to correct for the impact of aerosol scattering based on the correction scheme by Anderson and Ogren (1998) and using correction factors obtained by Müller et al. (2011) without a submicron size cut-off. Uncertainties in the absorption coefficient are of the order of $30 \%$ (Müller et al., 2011). The nephelometer was calibrated with particle-free air and high-purity $\mathrm{CO}_{2}$ prior to and after the campaign.

Prior to the campaign, the CAPS data were evaluated against the combination of the nephelometer and the PSAP measurements. The instrument intercomparison has been performed with purely scattering ammonium sulfate particles and with strongly absorbing black carbon particles. Both types of aerosols were generated by nebulizing a solution of the respective substances and size-selected using a differential mobility analyser. For instrument intercomparison purposes, the extinction coefficient from the nephelometer and PSAP was adjusted to that for $530 \mathrm{~nm}$ by using the scattering and absorption Angstrom exponent. The instrument evaluation showed an excellent accuracy of the CAPS measurements by comparison to the combination of nephelometer and PSAP measurements. The level of uncertainty obtained for the test aerosol was beyond the upper limit of the CAPS uncertainty, which was estimated to be $\pm 3 \%$ according to Massoli et al. (2010).
Total particle concentrations for particle diameters above $10 \mathrm{~nm}\left(N_{10}\right)$ are measured using a Condensational Particle Counter (CPC, model MARIE built by the University of Mainz), calibrated prior to the experiment (sampling time $1 \mathrm{~Hz}$ ). The associated uncertainty is of the order of $10 \%$. Aerosol optical size in the range $0.25-25 \mu \mathrm{m}$ is measured using an Optical Particle Counter (OPC, model 1.109 from GRIMM Technologies) in 32 channels, with a $6 \mathrm{~s}$ sampling rate. Particulate matter number concentrations for size ranges smaller than $1 \mu \mathrm{m}$, between 1 and $2.5 \mu \mathrm{m}$ and between 2.5 and $10 \mu \mathrm{m}$, are computed from the OPC, and are referred to as $N_{\mathrm{PM}_{1}}, N_{\mathrm{PM}_{2.5}}$, and $N_{\mathrm{PM}_{10}}$, respectively, in the following. The GRIMM OPC was calibrated with size-standard particles prior to and after the field campaign.

Sampling with all the above-mentioned instruments is achieved through the Community Aerosol Inlet of the ATR 42.

Regarding gas-phase chemistry, we make use of an $\mathrm{O}_{3}$ analyser and a $\mathrm{NO}_{x}$ analyser from Thermo Environmental Instruments (TEI Model 49i and TEI 42CTL, respectively). The associated uncertainty is of the order of 5 and $10 \%$, respectively. Carbon monoxide (CO) measurements are performed using the near-infrared cavity ring-down spectroscopy technique (G2401, Picarro Inc., Santa Clara, CA, USA), with a time resolution of $5 \mathrm{~s}$.

All in-cloud measurements are removed from the data shown here.

\subsection{Space-borne observations}

The Spinning Enhanced Visible and Infra-Red Imager (SEVIRI), onboard Meteosat Second Generation (MSG), measures aerosol optical depth (AOD) with spatial and temporal resolutions of $10 \mathrm{~km}$ and $15 \mathrm{~min}$, respectively (Bennouna et al., 2009). We use the operational version 1.04 of the AOD product at $550 \mathrm{~nm}$, downloaded from the ICARE data service center (http://www.icare.univ-lille1.fr/, last access: $16 \mathrm{Au}$ gust 2018).

The Moderate Resolution Imaging Spectroradiometer (MODIS, Salmonson et al., 1989; King et al., 1992) flies aboard polar-orbiting platforms Aqua and Terra. Terra crosses the Equator from north to south in the morning ( $\sim 10: 30$ local time), whereas Aqua crosses from south to north during the afternoon ( 13:30 local time). They provide a complete coverage of the Earth's surface in 1 to 2 days with a resolution between 250 and $1000 \mathrm{~m}$, depending on the spectral band. In the following, we use MODISderived level 2 AODs at $550 \mathrm{~nm}$ from both Terra and Aqua. Level 2 products are provided as granules with a spatial resolution of $10 \mathrm{~km}$ at nadir. The standard deviation on the AOD retrieval (Remer et al., 2005) over land (ocean) is $0.15 \pm 0.05 \times \mathrm{AOD}(0.05 \pm 0.03 \times \mathrm{AOD})$. We also use level 3 daily sea surface temperature (SST) data derived from the $11 \mu \mathrm{m}$ thermal infrared band available at $9.26 \mathrm{~km}$ spatial resolution for daytime passes (Werdell et al., 2013). 
The hourly land surface temperature products from the Copernicus Global Land Service (https://land.copernicus.eu/ global/products/lst, last access: 16 August 2018) used in this study are available at $5 \mathrm{~km}$ spatial resolution. The radiative skin temperature of the land surface is estimated from the infrared spectral channels of sensors onboard a constellation of geostationary satellites (among them SEVIRI on MSG). Its estimation further depends on the surface albedo, the vegetation cover, and the soil moisture.

The Cloud-Aerosol LIdar with Orthogonal Polarization (CALIOP) flies onboard the Cloud-Aerosol Lidar Pathfinder Satellite Observation (CALIPSO), following a similar polar orbit to Aqua within the A-train constellation. In this work, we use CALIOP level-2 data (version 4.10) below $8 \mathrm{~km}$ above mean sea level (a.m.s.l.; https://www-calipso. larc.nasa.gov/products/, last access: 16 August 2018). Details on the CALIOP instrument, data acquisition, and science products are given by Winker et al. (2007). We mainly consider the aerosol typing, which was corrected in version 4.10, as described in Burton et al. (2015).

\subsection{Radiosounding network}

During the DACCIWA field campaign, the upper air network was successfully augmented in June and July 2016 to a spatial density unprecedented for SWA (see Flamant et al., 2018). In this study, we use radiosounding data from meteorological balloons launched in Abidjan, Accra, and Cotonou on the afternoon of 2 July (see Fig. 1). The management of soundings at Abidjan and Cotonou was subcontracted to a private company, while the Ghana Meteorological Agency took care of the soundings in Accra. The Karlsruhe Institute of Technology was instrumental in the Ghana sounding and staff from the Agence pour la Sécurité de la Navigation Aérienne en Afrique et à Madagascar helped with the Abidjan and Cotonou soundings.

\section{Models and simulations}

\subsection{ECMWF operational analyses and CAMS forecasts}

For the investigation of atmospheric dynamics at the regional scale, we use operational analyses from the Integrated Forecasting System (IFS, a global data assimilation and forecasting system) developed by the European Centre for MediumRange Weather Forecasts (ECMWF). The analyses presented in this paper are associated with IFS model cycle CY41r2. The original $\mathrm{T}_{\mathrm{CO}} 1279(\mathrm{O} 1280)$ resolution of the operational analysis was transformed onto a $0.125^{\circ}$ regular latitudelongitude grid. Long-range transport of biomass burning and dust-laden air masses transported over the Gulf of Guinea are monitored with respective optical depths at $550 \mathrm{~nm}$ calculated from the ECMWF Copernicus Atmosphere Monitoring Service-Integrated Forecasting System (CAMS-IFS; Flemming et al., 2015) available at a resolution of $0.4^{\circ}$.

\subsection{WRF and CHIMERE simulations}

The WRF model (version v3.7.1, Shamarock and Klemp, 2008) and the CHIMERE chemistry-transport model (2017 version, Mailler et al., 2017) are used in this study. WRF calculates meteorological fields that are then used in offline mode by CHIMERE to (i) conduct tracer experiments and (ii) compute backplumes. WRF and CHIMERE simulations are performed on common domains. For the period 30 June3 July 2016, two simulations are conducted for both WRF and CHIMERE to provide insights into the airborne observations: a simulation with a $10 \mathrm{~km}$ mesh size in a domain extending from $1^{\circ} \mathrm{S}$ to $14^{\circ} \mathrm{N}$ and from $11^{\circ} \mathrm{W}$ to $11^{\circ} \mathrm{E}$ (larger than the domain shown in Fig. 1a) and a simulation with a $2 \mathrm{~km}$ mesh size in a domain extending from 2.8 to $9.3^{\circ} \mathrm{N}$ and from $2.8^{\circ} \mathrm{W}$ to $3.3^{\circ} \mathrm{E}$ (Fig. 1a).

The nested WRF simulations are first performed with hourly outputs. For the two horizontal resolutions, the same physical parameterizations are used and are those described in Deroubaix et al. (2018). The ABL scheme is the one proposed by Yonsei University (Hong et al., 2006), the microphysics is calculated using the Single Moment- 6 class scheme (Hong and Lim, 2006), the radiation scheme is RRTMG (Mlawer et al., 1997), the cumulus parameterization is the Grell-Dévényi scheme, and the surface fluxes are calculated using the Noah scheme (Ek et al., 2003). The $10 \mathrm{~km}$ WRF simulation uses National Centers for Environmental Prediction (NCEP) Final global analyses as initial and boundary conditions. NCEP Real-Time Global SSTs (Thiébaux et al., 2003) are used as lower boundary conditions over the ocean. The meteorological initial and boundary conditions for the $2 \mathrm{~km}$ WRF simulation are provided by the $10 \mathrm{~km}$ WRF run, which, in turn, receives information from the $2 \mathrm{~km}$ WRF simulation (two-way nesting). The chemistry and aerosol initial and boundary conditions for the $2 \mathrm{~km}$ CHIMERE simulation are provided by the $10 \mathrm{~km}$ simulation (one-way nesting). The simulations are carried out using 32 vertical sigma-pressure levels from the surface to $50 \mathrm{hPa}$, with 6 to 8 levels in the ABL.

Then the CHIMERE simulations are performed. The horizontal grid is the same as WRF. Vertically, CHIMERE uses 20 levels from the surface to $300 \mathrm{hPa}$ and three-dimensional meteorological fields are vertically interpolated from the WRF to the CHIMERE grid. The two-dimensional fields, such as $10 \mathrm{~m}$ wind speed, $2 \mathrm{~m}$ temperature, surface fluxes, and boundary-layer height are used directly in CHIMERE. The chemistry and aerosol initial and boundary conditions for the $2 \mathrm{~km}$ CHIMERE simulation are provided by the $10 \mathrm{~km}$ simulation (one-way nesting).

The representation of the atmospheric dynamics in the $2 \mathrm{~km}$ simulation was verified against dynamical and thermodynamical observations from both aircraft (Fig. S1 in the Supplement) and the DACCIWA radiosounding network from Accra and Cotonou (Fig. S2), yielding satisfactory results. For each aircraft and sounding data point, the corre- 
sponding WRF grid cell value is extracted. A bilinear interpolation is performed horizontally to exactly match the horizontal position of the balloon or aircraft. Linear interpolations are also performed vertically between two WRF levels as well as temporally between two consecutive model outputs to match the altitude of the balloon or aircraft at the time the pressure, temperature, humidity, and wind observations are made.

\subsubsection{Tracer experiments}

A series of numerical tracer experiments were conducted to aid interpretation of airborne observations, particularly by separating (locally emitted) urban pollution from long-range transported aerosol plumes. Passive tracers were set to be released from four major coastal cities: Accra (Ghana, $5.60^{\circ} \mathrm{N}$, $0.19^{\circ} \mathrm{W}$ ), Lomé (Togo, $\left.6.17^{\circ} \mathrm{N}, 1.23^{\circ} \mathrm{E}\right)$, Cotonou (Benin, $6.36^{\circ} \mathrm{N}, 2.38^{\circ} \mathrm{E}$ ), and Lagos (Nigeria, $6.49^{\circ} \mathrm{N}, 3.36^{\circ} \mathrm{E}$ ). We conducted two sets of experiments, one for which emissions from the cities are identical (TRA_I, with "I" standing for "identical") and one for which the emissions are different and proportional to the size of the population (TRA_D, with "D" standing for "different"), based on the World Urbanization Prospect report (2015). In the latter case, emissions from Lomé, Accra, and Lagos are scaled to Cotonou emissions (1.8, 3, and 13 times, respectively). Large cities in developing countries are generally considered to generate an atmospheric pollution roughly proportional to their total population due to a lack of adequate emission policies. Tracers are emitted in the lowest level of the model (below $10 \mathrm{~m}$ altitude) during the period of interest: in experiences TRA_D12 and TRA_I12, tracers are emitted continuously on 1 and 2 July, while in experiences TRA_D1 and TRA_D2, tracer emissions only occur on 1 and 2 July, respectively. Emissions take place in a $2 \mathrm{~km} \times 2 \mathrm{~km}$ mesh for each city. For the sake of simplicity, emissions are constant in time and thus do not have a diurnal cycle. Tracer concentrations in the atmosphere are then shown in arbitrary units (a.u.) and coloured according to the city: blue for Accra, green for Lomé, and red for Cotonou.

\subsubsection{Backplumes}

Backplumes (or back-trajectory ensembles) are computed according to Mailler et al. (2016), using a dedicated regional CHIMERE simulation with a mesh size of $30 \mathrm{~km}$, covering the whole of Africa. The objective is to assess the origin of an elevated aerosol layer observed with the ULICE lidar (see Sect. 5). For this study, 50 tracers are released at the same time for selected locations along the ATR 42 flight trajectory, where large aerosol contents are observed: (i) the southernmost part of the flight $\left(2.0^{\circ} \mathrm{W}, 4.5^{\circ} \mathrm{N}\right)$ and (ii) the northernmost part of the flight $\left(1.0^{\circ} \mathrm{E}, 5.5^{\circ} \mathrm{N}\right)$. For both locations, backplumes are launched at $2500 \mathrm{~m}$ a.m.s.l. on 2 July 2016 at 17:00 UTC (i.e. the height of the elevated aerosol layer above the Gulf of Guinea; see Sect. 5). Very similar results are obtained for both backplumes. A similar sensitivity analysis is conducted by changing the altitude of the backplume from $2500 \mathrm{~m}$ to $3500 \mathrm{~m}$ a.m.s.l., but the effect is small (not shown). There again, very similar results are obtained for both backplumes. Hence, in the following we shall only show results from the backplume released from the northernmost location at $2500 \mathrm{~m}$ a.m.s.1.

\section{Synoptic situation and airborne operations on 2 July 2016}

The entire DACCIWA aircraft campaign took place during WAM post-onset conditions (Knippertz et al., 2017), i.e. after the migration of the climatological precipitation maximum from the coast to the Sahel, with the monsoon flow being well established over SWA. The campaign took place after the onset of the Atlantic Cold Tongue as evident in Fig. 3 of Knippertz et al. (2017), which also highlights that the coastal upwelling started progressively building up around 27 June 2016.

In the period spanning from 29 June to 5 July 2016, the major weather disturbances over SWA are associated with African easterly waves travelling along the well-organized African easterly jet (AEJ). A cyclonic centre propagating to the south of the AEJ (identified from ECMWF $850 \mathrm{hPa}$ streamline charts, not shown) originated from eastern Nigeria on 29 June, sweeping through SWA during the following days.

On 2 July 2016, the cyclonic centre is located at the coast of Sierra Leone (see the disturbance labelled "F" in Fig. 14 of Knippertz et al., 2017). The monsoonal winds are almost southerly over the Gulf of Guinea (south of $4^{\circ} \mathrm{N}$ ) and progressively veer to southwesterly farther north and over the continent (Fig. S3a). In the mid-troposphere, SWA is under the influence of easterly flow conditions (Fig. S3b). West of $5^{\circ} \mathrm{E}$, the AEJ is located over the Sahel and is intensified along its northern boundary by a strong Saharan high located over Libya. The AEJ maximum is seen off the coast of Senegal.

The region of interest experiences high insolation on 1 July with temperatures in the 30 s of ${ }^{\circ} \mathrm{C}$ across SWA and widespread low-level clouds dissolving rapidly in the course of the morning. On 2 July, there is a clear indication of land-sea breeze clouds in the high-resolution SEVIRI image at 12:00 UTC (Fig. 2a) with relatively cloud-free conditions over the ocean, where the ATR 42 flew later on. The land-sea breeze front is seen inland to follow the coastline from western Ghana to western Nigeria. The front is observed to move farther inland until 15:00 UTC (Fig. 2b) with shallow convective cells forming along it. Farther south the area is free of low-level clouds (both over land and ocean). Oceanic convection occurred offshore on the previous day and mesoscale convective systems were present over northern-central Nige- 
(a)

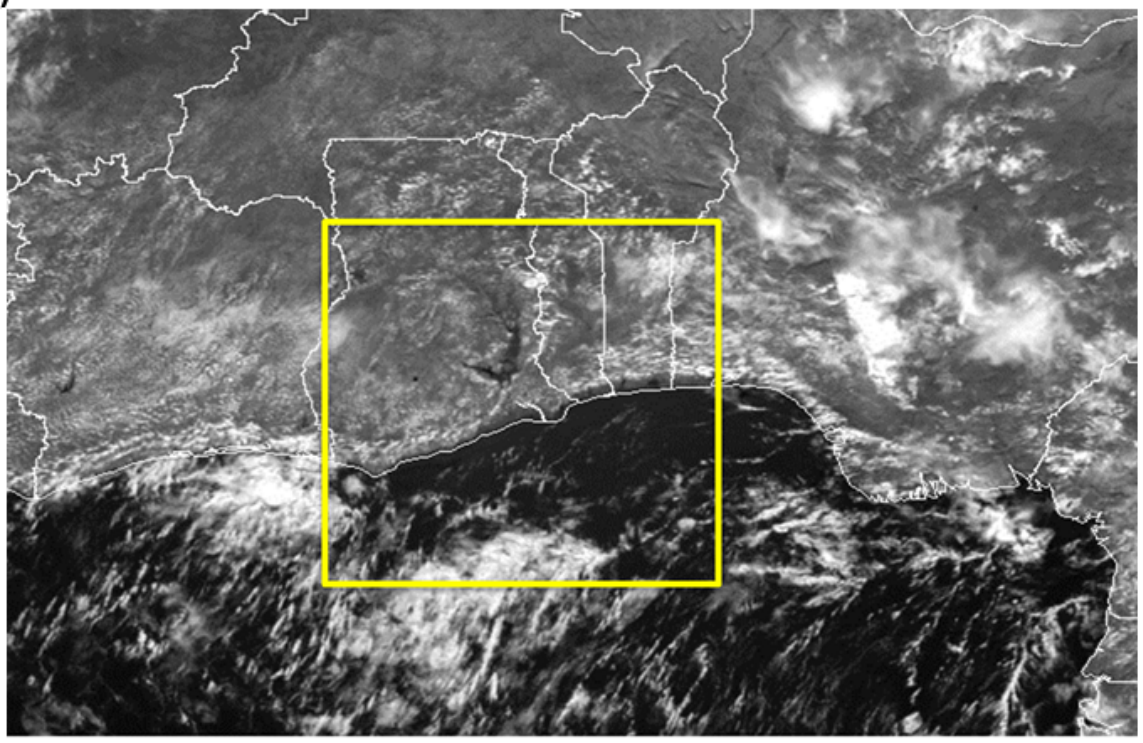

(b)

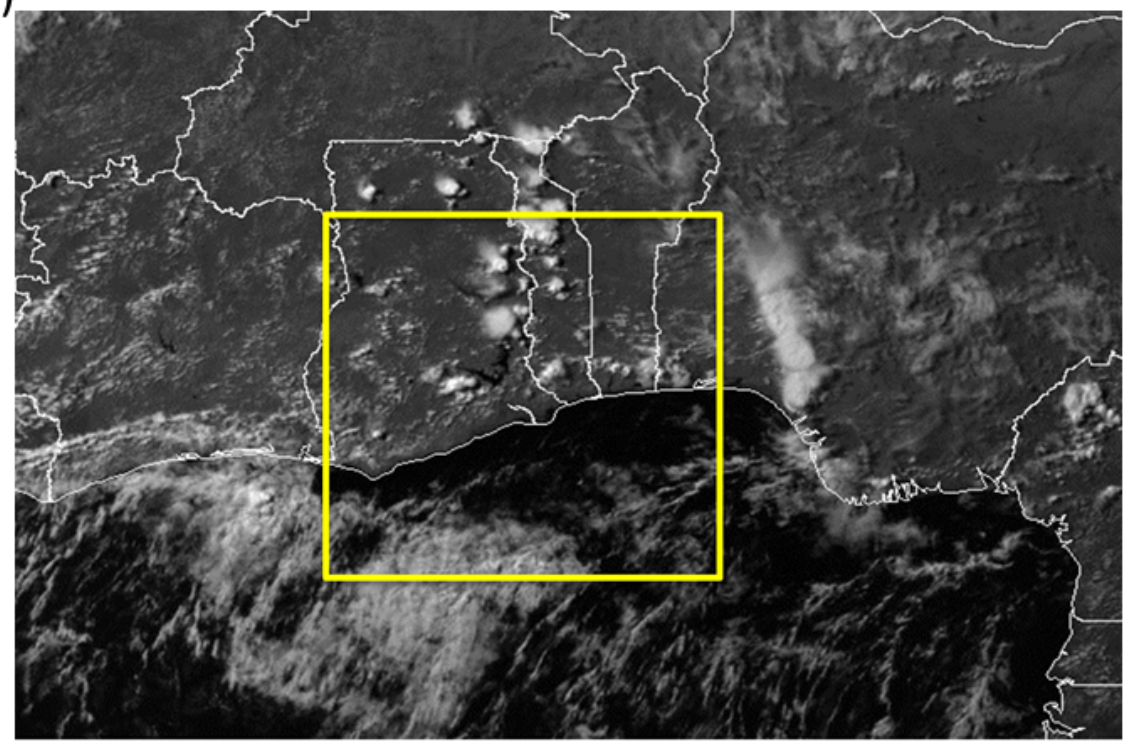

Figure 2. SEVIRI visible images of SWA on 2 July at (a) 12:00 UTC and (b) 15:00 UTC. Country borders are shown as solid white lines. The yellow thick box represents the domain of the $2 \mathrm{~km}$ WRF simulation as in Fig. 1a. The coordinates of the lower left corner of the images are $0^{\circ} \mathrm{N} / 8^{\circ} \mathrm{W}$, and the coordinates of the upper right corner of the images are $13^{\circ} \mathrm{N} / 10^{\circ} 45^{\prime} \mathrm{E}$.

ria on the morning of 2 July. Satellite images show both oceanic and inland convection to be decaying by midday (Fig. 2a).

On 2 July, the ATR 42 aircraft took off from Lomé at 14:45 UTC (NB: UTC equals local time in July in Togo) and headed towards the ocean, flying almost parallel to the Ghana coastline (Fig. 1a) at low level (in the marine ABL). Before reaching Cape Three Points (close to the border between Ghana and Ivory Coast), the ATR 42 changed direction and headed south. Upon reaching its southernmost position $\left(\sim 3^{\circ} \mathrm{N}\right)$, the ATR 42 turned around, climbed to
$3200 \mathrm{~m}$ a.m.s.l., and finally headed back to Lomé at that level. On the way back, the aircraft changed, heading around 16:53 UTC to fly along the coast prior to landing. The ATR 42 passed the longitude of Accra at 17:29 UTC and landed in Lomé at 18:07 UTC. The high-level flight back allowed mapping out of the vertical distribution of aerosols and clouds using the ULICE lidar. In situ aerosol- and gas-phase chemistry measurements will be used in the following to characterize the composition of aerosols and related air masses sampled with the lidar, particularly during the ascent over the ocean (between 16:33 and 16:47 UTC), the elevated levelled run, 
and the descent towards Lomé airport (between 17:53 and 18:07 UTC).

\section{Atmospheric composition over the Gulf of Guinea and the link with lower tropospheric circulation}

Figure 3 shows ULICE-derived ASR and VDR cross sections acquired between 16:40 and 18:00 UTC, including data gathered during the aircraft ascent over the ocean and descent in the vicinity of the coast. It is worth noting that most of the lidar data shown in Fig. 3 were acquired while the aircraft was flying along the coastline (from 16:53 UTC on). Wind measurements from the Abidjan, Accra, and Cotonou soundings as well as from the ATR 42 sounding over the ocean clearly show that above $1.2 \mathrm{~km}$ a.m.s.l. the flow is easterly over the region of aircraft operation (Fig. 4). Given that the heading of the aircraft along this elevated leg is $65^{\circ}$, the lidar "curtains" above $1.2 \mathrm{~km}$ a.m.s.l. in Fig. 3 map out aerosol layers that are transported westward (with the ATR 42 flying against the mean flow).

Several outstanding features are highlighted in Fig. 3. Generally few clouds were encountered along the flight track (they appear in dark red colours). Exceptions are the lowlevel clouds at the top of the marine ABL with a base around $500 \mathrm{~m}$ a.m.s.l. to the west of the track between 16:55 and 17:02 UTC (Fig. 3a). The vertical extension and the number of the cumulus clouds topping the marine ABL decrease towards the east. This shoaling of the marine ABL is likely ascribed to the increasing trajectory length of near-surface parcels over the cold coastal waters (as the aircraft flies over the coastal upwelling region). Near Lomé, the top of the marine ABL can only be identified from the higher ASR values, reflecting the impact of high relative humidity on the scattering properties of the marine aerosols (Fig. 3a). An isolated deeper convective cloud is observed before 16:48 UTC between 2 and $2.5 \mathrm{~km}$, which is also sampled in situ by the ATR 42 cloud probes. The top of the cloud is likely connected to a temperature inversion observed during the aircraft ascent over the ocean (not shown). High lidar-derived ASRs are observed near the marine ABL top and to some extent in the mixed layer (Fig. 3a). The ASR-enhanced layers do not show in the VDR plot, possibly because they are related to the presence of sea-salt aerosols, which are spherical particles that do not depolarize the backscattered lidar signal. However, the high ASR values could also be related to the advection of biomass burning aerosols from the south in the marine ABL (e.g. Menut et al., 2018) as suggested by the relatively high $\mathrm{CO}$ and extinction coefficient values observed in the ABL over the ocean (110 ppb and $50 \mathrm{Mm}^{-1}$, respectively) in Fig. 5c and e. Biomass burning aerosols are also generally associated with low VDR values.

In addition to clouds and marine ABL aerosols, several distinct aerosol features in the free troposphere stand out from the lidar plot.
- Features A and B correspond to plumes with high values of ASR (larger than 1.2) and VDR (larger than $0.8 \%$ ) observed near the coast between the surface and $0.5 \mathrm{~km}$ a.m.s.l. and between 0.5 and $1.5 \mathrm{~km}$ a.m.s.l., respectively, during the aircraft descent towards Lomé. According to the aircraft in situ observations, feature $\mathrm{B}$ is located in a strong wind shear environment at the top $(\sim 600 \mathrm{~m})$ of the ABL (Fig. 4$)$ with its upper part being located in the easterly flow, while feature A is associated with a south-southwesterly flow. This sheared environment likely explains the slanted structure of the aerosol plume associated with feature B.

- Feature $\mathrm{C}$ is an intermediate aerosol layer characterized by VDR values lower than those for feature B, suggesting more spherical (possibly more aged pollution) aerosols. This feature is bounded by much lower VDR values, especially above, while being associated with higher ASR values than its immediate environment. This feature is slanted between Lomé and the deeper isolated cloud. The layer thickness is larger near Lomé than over the more remote ocean, leading to a less slanted layer top. This layer has also been sampled in situ by the ATR 42 during its ascent over the ocean. It is characterized by VDRs of the order of $0.7 \%$. Based on the aircraft sounding data, it appears that this layer is mostly advected with the easterly flow above $1.2 \mathrm{~km}$ a.m.s.l. (Fig. 4).

- Feature D is an elevated aerosol layer observed at the level of the aircraft (i.e. at $3200 \mathrm{~m}$ a.m.s.l.) in the vicinity of Lomé, which was also sampled in situ by the ATR 42. This layer is separated from feature B by a $\sim 500 \mathrm{~m}$ deep layer of non-depolarizing aerosols (very low VDRs). The base of this layer exhibits a slanting similar to the one observed for the top of the intermediate aerosol layer (feature B). Large VDRs are found in the core of this feature $(>1.2 \%)$. It appears that this layer is also advected with the easterly flow above $1.2 \mathrm{~km}$ a.m.s.l.

- Feature E is also an elevated aerosol layer, but observed farther south over the ocean and in the vicinity of the isolated deeper cloud. It is characterized by large ASR values but low VDR values (suggesting the presence of low-depolarizing aerosols).

Given the distance of the oceanic profile to the coast $(\sim$ $100 \mathrm{~km}$ ), we consider the oceanic (ascending) profile to be representative of background aerosol- or gas-phase conditions upstream of coastal SWA. Using this profile as a reference, we have analysed the characteristics of the aerosol plume sampled with the ATR 42 (both in situ and remotely) during the aircraft descent over Lomé. The most significant differences between the ATR 42 observations acquired during the oceanic profile and the profile over Lomé are found 
(a)

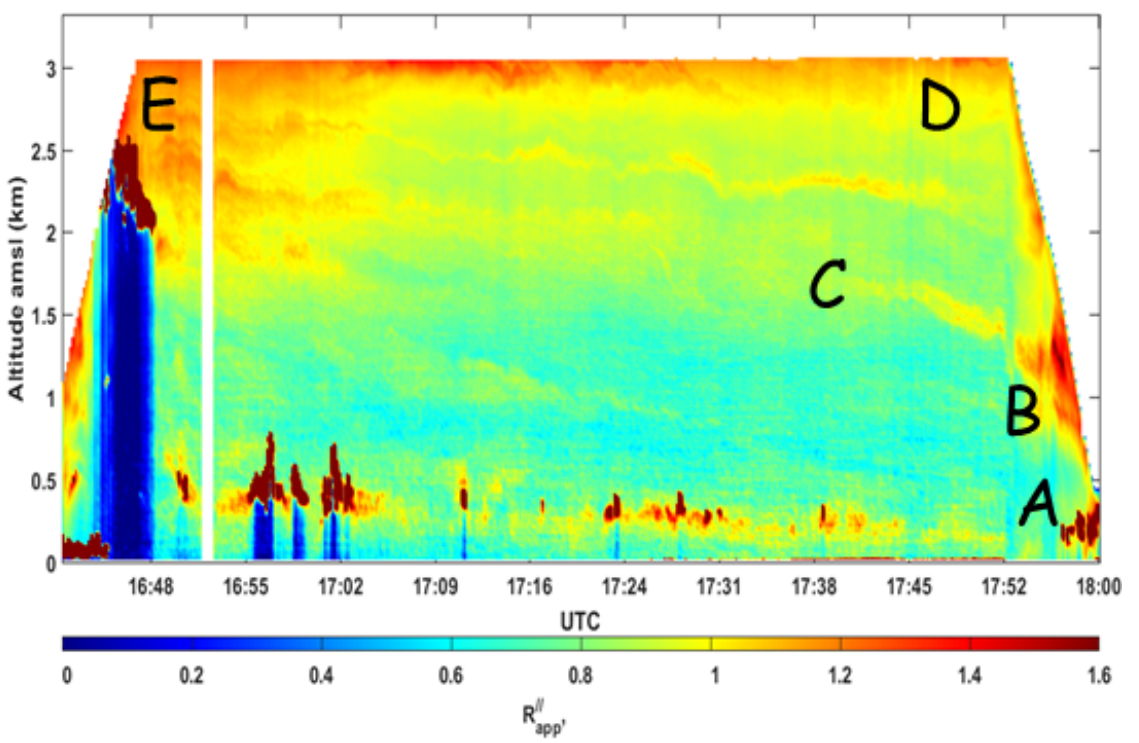

(b)

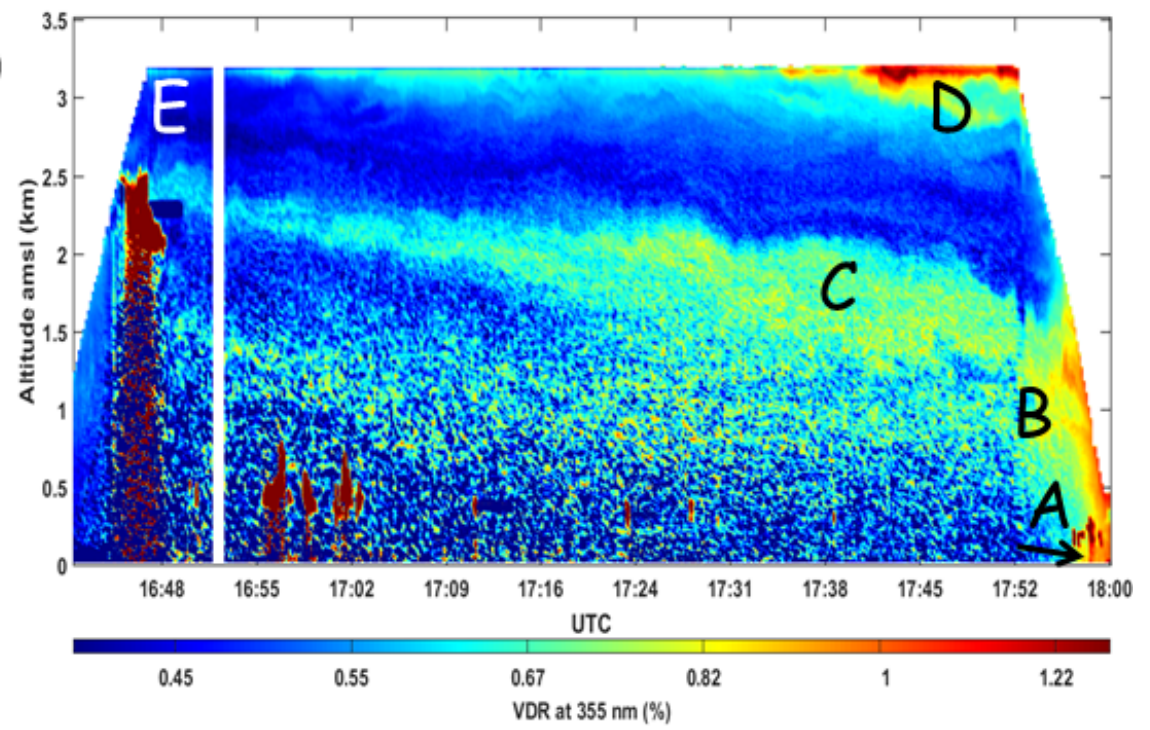

Figure 3. Time-height evolution of the ULICE-derived (a) apparent scattering ratio $\left(R_{\mathrm{app}}\right)$ and (b) volume depolarization ratio (VDR) below the ATR 42 flight track over the Gulf of Guinea between 16:44 and 18:00 UTC on 2 July 2016 (see Fig. 1a). The ATR leg parallel to the coastline starts at 16:54 UTC. The ATR passed the longitude of Accra at 17:29 UTC. See text for explanations of features A-E. The arrow in (b) points to feature A. The distance covered by the ATR 42 along this transect is $\sim 450 \mathrm{~km}$.

below $1.7 \mathrm{~km}$ a.m.s.l. (Fig. 5) and are associated with features $\mathrm{A}$ and $\mathrm{B}$.

ATR 42 observations associated with feature A (below 0.5 km a.m.s.l.) show increases in $\mathrm{NO}_{x}, \mathrm{CO}$, and $\mathrm{PM}_{1}$ aerosol concentrations (Fig. 5a, c, f, respectively) as well as an extinction coefficient (Fig. 5e), together with an $\mathrm{O}_{3}$ concentration reduction (Fig. 5b). Plume A is related to fresh anthropogenic emissions from Lomé, including $\mathrm{NO}_{x}$. The addition of a large quantity of $\mathrm{NO}_{x}$ into the atmosphere can lead to a significant shift in the ozone chemical equilibrium, which can effectively result in near-source consumption, as observed here. No CPC-derived aerosol concentrations are available below $0.5 \mathrm{~km}$ a.m.s.l. The few PSAP mea- surements made around $0.5 \mathrm{~km}$ a.m.s.l. during the descent yield an AAE value around $\sim 1$ (Fig. $5 \mathrm{~g}$ ). These are solid indications that the ATR 42 sampled a fresh urban anthropogenic plume near Lomé (Brito et al., 2018), advected with the south-southwesterly monsoon flow (the ATR 42 being downstream of Lomé then).

ATR 42 observations associated with feature B (between 0.5 and $1.5 \mathrm{~km}$ a.m.s.l.) show increases in concentrations for all variables under scrutiny, including $\mathrm{O}_{3}$. The latter (Fig. 5b) is the most significant difference between the characteristics of features B and A. Other differences include the much smaller increases in $\mathrm{CO}$ concentration and OPC aerosol $\left(N_{\mathrm{PM}_{1}}, N_{\mathrm{PM}_{2.5}}\right.$, and $\left.N_{\mathrm{PM}_{10}}\right)$ concentrations as well 
(a)

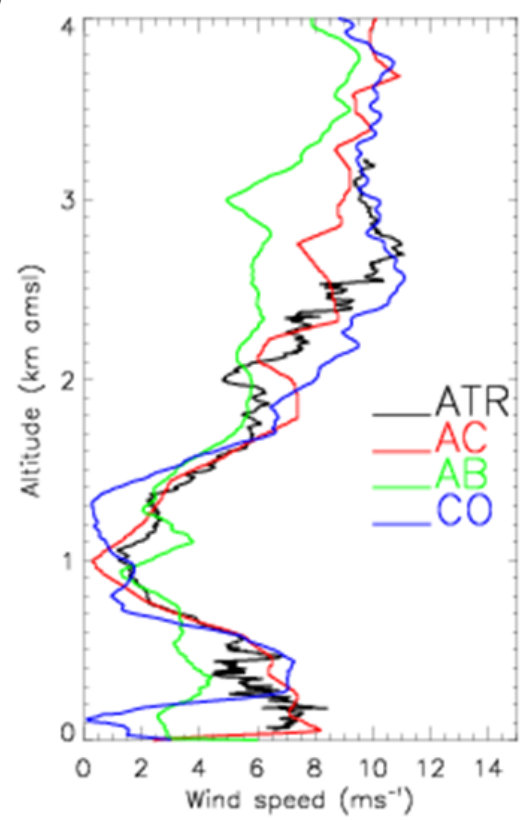

(b)

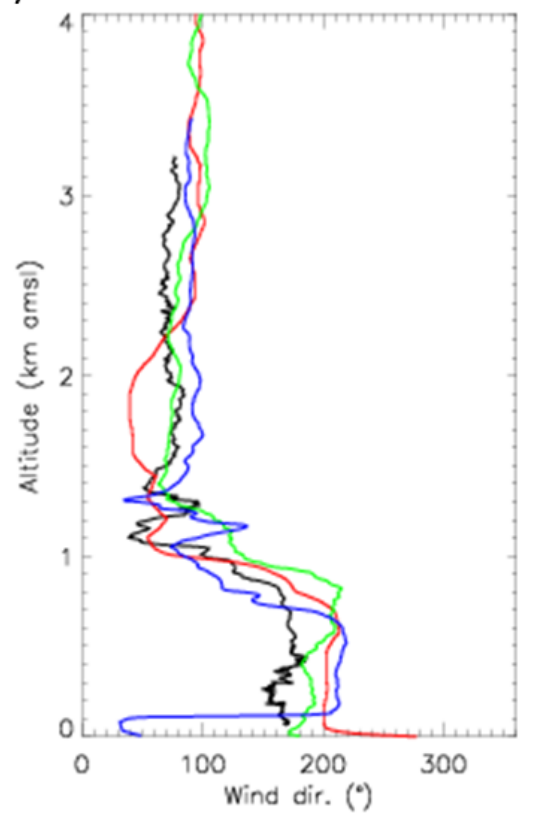

Figure 4. (a) Wind speed and (b) wind direction profiles measured during the ATR 42 sounding over the ocean (16:30 to 16:47 UTC, ATR, black solid line) as well as from the radiosoundings launched in Accra at 17:00 UTC (AC, red solid line), in Abidjan at 16:08 UTC (AB, green solid line), and in Cotonou at 16:12 UTC (CO, blue solid line). The location of the radiosounding sites is shown in Fig. 1a.

as extinction coefficients observed in feature B (Fig. 5c, e, $\mathrm{f}$, respectively). The $\mathrm{O}_{3} / \mathrm{CO}$ ratio (an indicator of air mass aging, e.g. Jaffe and Wigder, 2012, and Kim et al., 2013) observed to be associated with feature B increases with respect to feature A $(0.25$ vs. 0.15 , i.e. a $65 \%$ increase $)$, which is compatible with a further processed urban plume, as also corroborated by wind measurements. These observations, together with wind measurements, suggest that feature B corresponds to a more aged urban plume. This could be an indication that the ATR 42 sampled more than just the Lomé plume. This will be investigated using tracer experiments in Sect. 6. Above $2 \mathrm{~km}$ a.m.s.1., the AAE increases to larger values $(>1.5)$, evidencing a change in aerosol nature, i.e. a transition from local urban emissions to elevated background pollution (Fig. $5 \mathrm{~g}$ ), possibly resulting from a mixture of longlived anthropogenic pollution and long-range transport of dust and biomass burning aerosols from previous days.

Regarding feature $\mathrm{C}$, the in situ measurements do not allow characterization of the nature of the aerosols. The origin of this layer will also be investigated using tracer experiments (see Sect. 6).

The in situ measurements along the elevated ATR 42 track reveal significant differences in aerosol- or gas-phase concentrations and properties between the western part (where feature $\mathrm{E}$ is observed with the lidar) and the eastern part (where feature D is observed) of the ATR 42 leg (Fig. 6). In the western part, ATR 42 measurements highlight enhanced $\mathrm{O}_{3}$ and $\mathrm{CO}$ concentrations ( $>60 \mathrm{ppbv}$ and $>200$ ppvb, re- spectively, Fig. 6a, b) together with AAE values of $\sim$ 1.5 (Fig. 6f), suggesting the presence of biomass burning aerosol. Furthermore, aerosol number concentrations $N_{\mathrm{PM}_{1}}$ and $N_{10}$ show enhanced values for small particles (100 and $\sim 1000$ no. $\mathrm{cm}^{-3}$, respectively, Fig. 6c, d). The observed $\mathrm{O}_{3}, \mathrm{CO}$, and $N_{10}$ concentrations are larger than the background values measured during the ascent over the ocean $(\sim$ 40 ppbv, 150 ppbv, and 500 no. $\mathrm{cm}^{-3}$, respectively, Fig. 5b, $\mathrm{c}, \mathrm{f})$. Large extinction values are also observed $\left(100 \mathrm{Mm}^{-1}\right)$, largely exceeding the background value of $30 \mathrm{Mm}^{-1}$ (compare Figs. 6e and 5e).

In the eastern part of the leg, AAE values of $\sim 1.5$ also suggest that biomass burning aerosols are sampled. $\mathrm{O}_{3}$, $\mathrm{CO}, N_{\mathrm{PM}_{1}}$, and $N_{10}$ concentrations diminish approximately halfway through the leg to their background values (from 17:16 UTC on, Fig. 6a, b, c, d), as does the extinction coefficient. However, $N_{\mathrm{PM}_{2.5}}$ and $N_{\mathrm{PM}_{10}}$ concentrations increase significantly, as opposed to $N_{\mathrm{PM}_{1}}$, which combined with enhanced lidar-derived VDR suggest mixing with larger particles, possibly dust. Further insight into the origin of these aerosols, observed as a result of long-range transport, will be investigated in Sect. 7.

Finally, in Sect. 8 we will investigate the cause of the slanting of the elevated aerosol layers from west to east along the flight track, which also possibly leads, in addition to the colder SSTs, to a thinning of the marine ABL and the suppression of clouds at its top in the vicinity of Lomé (Fig. 3). 
(a)

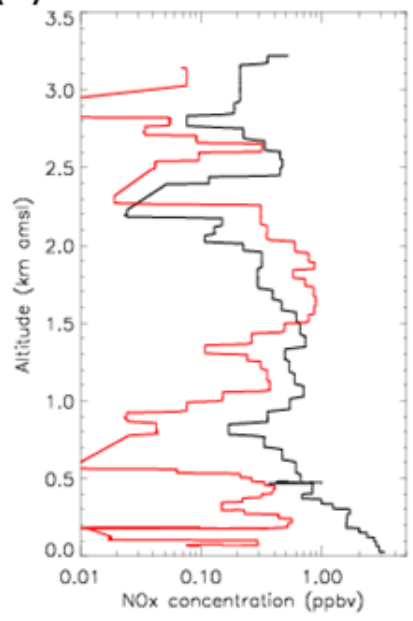

(e)

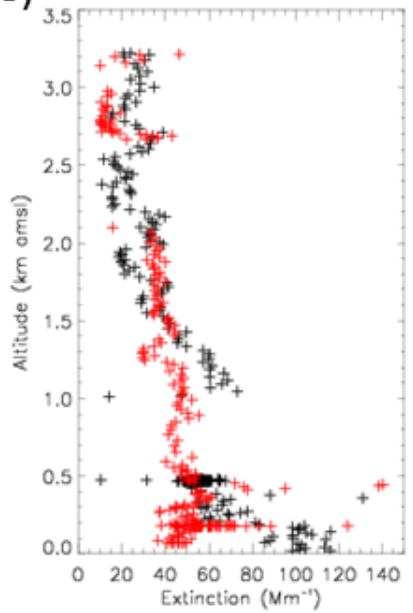

(b)

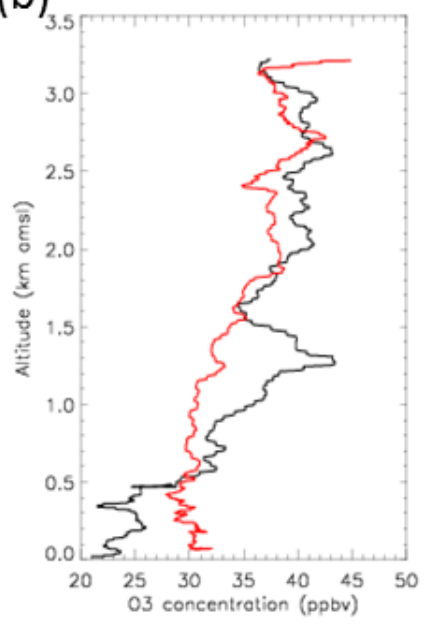

(f)

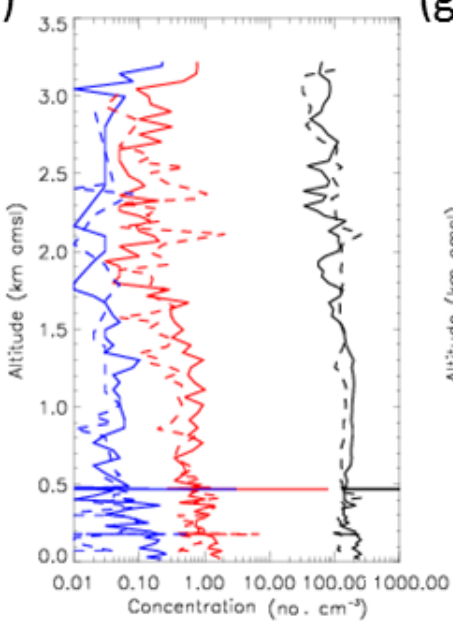

(c)

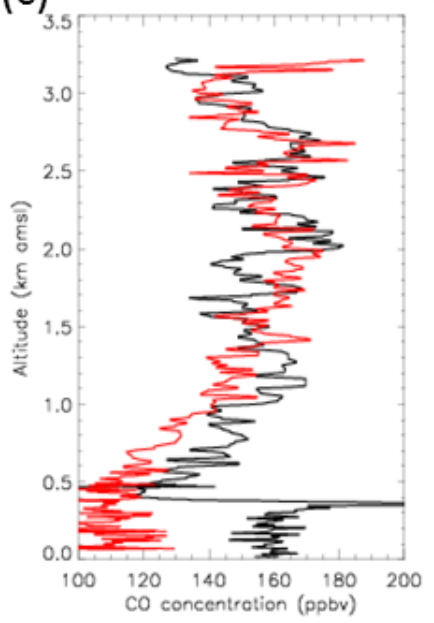

(g)

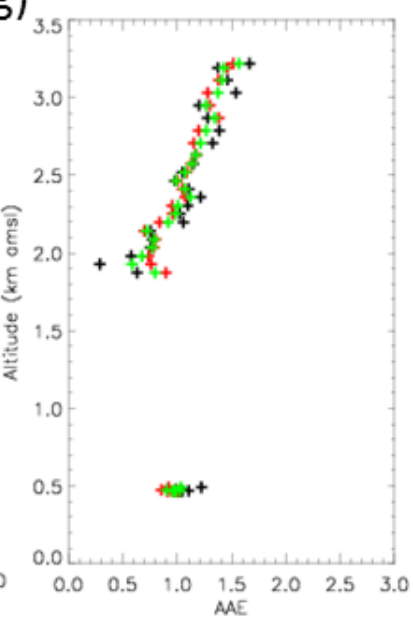

(d)

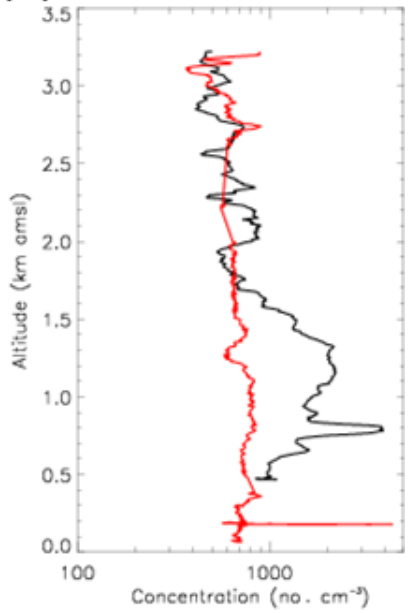

Figure 5. Profiles measured during the ATR 42 sounding over the ocean (16:33 to 16:47 UTC, red solid line) and at the coast in the vicinity of Lomé (17:53 to 18:07 UTC, black solid line) for (a) $\mathrm{NO}_{x}$ concentration, (b) $\mathrm{O}_{3}$ concentration, (c) CO concentration, (d) total aerosol concentration $N_{10}$ measured with the CPC, and (e) extinction coefficient. (f) $N_{\mathrm{PM}_{1}}, N_{\mathrm{PM}_{2.5}}$, and $N_{\mathrm{PM}_{10}}$ concentration profiles (black, red, and blue, respectively) measured over the ocean (dashed lines) and at the coast in the vicinity of Lomé (solid lines). (g) AAE profiles in the vicinity of Lomé computed between 467 and 530, 530 and 660, and 467 and $660 \mathrm{~nm}$ (black, red, and green solid symbols, respectively).

\section{Tracer experiments for anthropogenic aerosols}

The objectives of the tracer experiments are 3-fold: (i) understand how the lower tropospheric circulation shapes the structure of the urban pollution plume emitted from coastal cities and observed with the ULICE lidar (marked A and B in Fig. 3), (ii) assess which cities contribute to the plume observed with ULICE and whether it results from Lomé emissions only, and (iii) provide insight into the origin of the intermediate aerosol layer (marked B in Fig. 3). For this we have analysed along the ATR 42 aircraft flight track the tracer simulations introduced in Sect. 3.

As an ancillary objective, we also aim to assess how far over the ocean the urban pollution aerosols can be transported by the complex low-level circulation over SWA. For this, we have analysed the tracer simulations along four $0.5^{\circ}$ wide north-south transects spanning the longitudinal range of the ATR 42 flight (centered at $0.75^{\circ} \mathrm{W}, 0.25^{\circ} \mathrm{W}, 0.25^{\circ} \mathrm{E}$ and $0.75^{\circ}$ E; cf. Fig. 1b).

\subsection{Structure of the urban plume along the coastline}

Figure 7 shows the structure of the urban pollution plume along the aircraft track between 14:00 and 18:00 UTC in the TRA_D and TRA_I experiments. In TRA_D12 (Fig. 7a), feature A as observed in the lidar VDR field (Fig. 3) corresponds to emissions from Lomé only (in greenish colours) in the ABL (magenta dotted line), while feature B corresponds to emissions from Lomé mainly with a contribution from Accra (superimposed with the Lomé plume) and Cotonou (reddish colours in the upper western boundary of the Lomé 
(a)

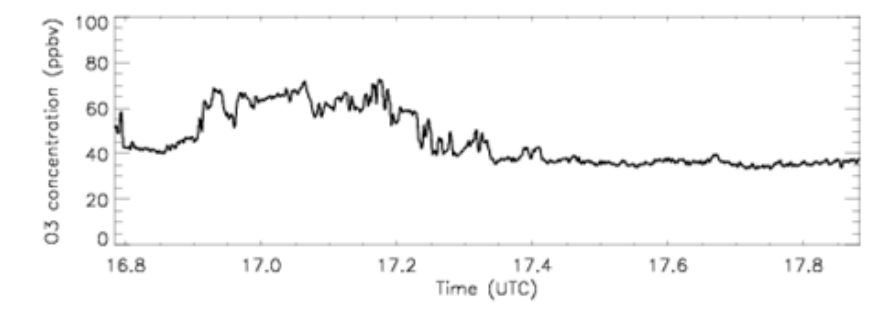

(c)

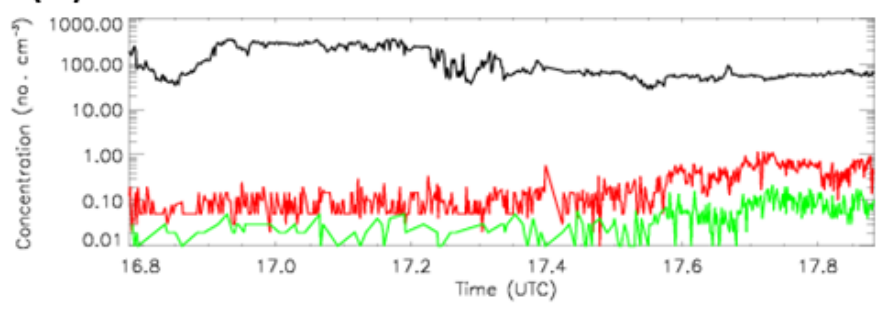

(e)

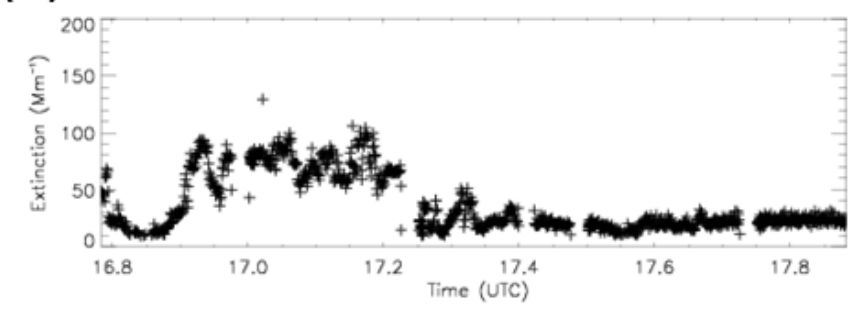

(b)

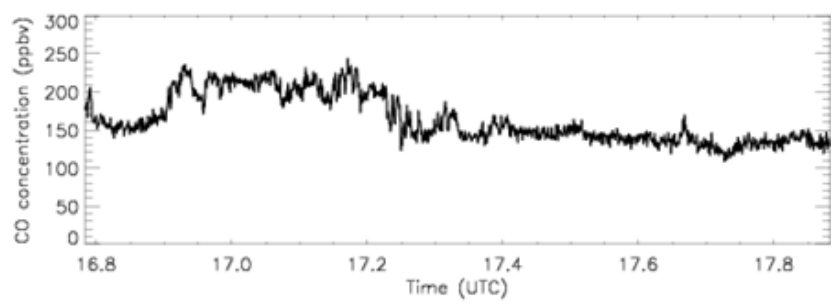

(d)

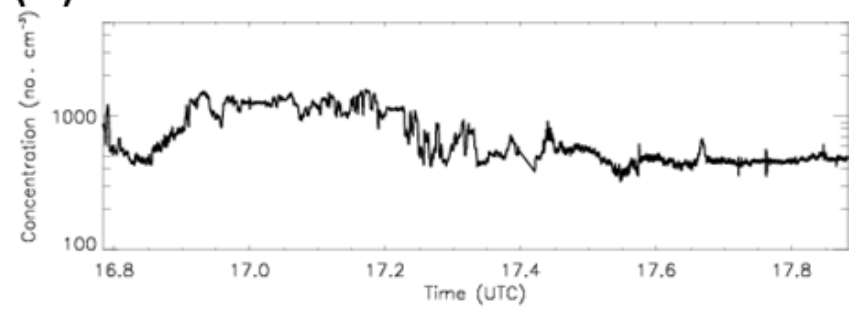

(f)

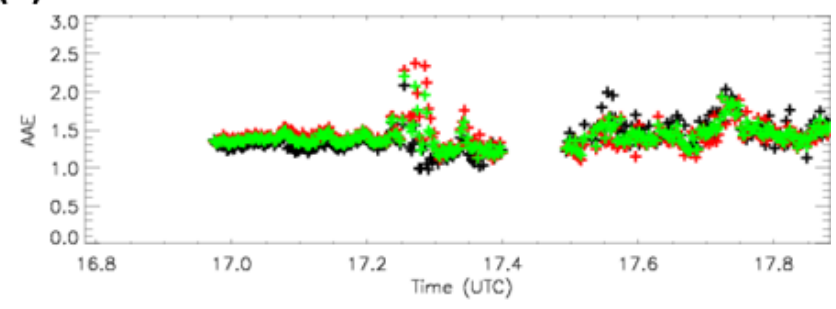

Figure 6. (a) $\mathrm{O}_{3}$ concentration, (b) $\mathrm{CO}$ concentration, (c) $N_{\mathrm{PM}_{1}}, N_{\mathrm{PM}_{2.5}}$, and $N_{\mathrm{PM}_{10}}$ concentrations (black, red, and green, respectively), (d) CPC-derived total aerosol concentration $N_{10}$, (e) extinction coefficient, and (f) AAE computed between 476 and 530, 530 and 660, and 476 and $660 \mathrm{~nm}$ (black, red, and green crosses, respectively) measured during the ATR 42 elevated straight level run from 16:47 to 17:53 UTC. The distance covered by the ATR 42 along this transect is $\sim 395 \mathrm{~km}$.

plume). In the TRA_I12 experiment, the Accra contribution is missing altogether (Fig. 7b). More strikingly, TRA_D2 shows an elevated tracer plume over the ocean originating from Accra (blueish colours), which mimics feature $\mathrm{C}$ in Fig. 3 fairly well. This feature is almost absent in TRA_I1, stressing the importance of accounting for enhanced emissions from Accra (with respect to Lomé and Cotonou) to produce a more realistic tracer simulation.

Results from experiment TRA_D1 (Fig. 7c) show that feature $\mathrm{C}$ in the lidar VDR observations is likely related to emissions from Accra from the previous day only (i.e. 1 July), as the structure of the Accra plume in TRA_D12 and TRA_D1 is the same. In experiment TRA_D1, the structures of the plume corresponding to features A and B in Fig. 3 are clearly altered by the lack of recent emissions in Lomé on 2 July (the lower part of the plume is likely advected northward with the southerly flow here). This is confirmed by looking at the result of TRA_D2 (Fig. 7d): the fresh emissions (on 2 July) from Lomé do lead to a realistic simulation of the shape of features A and B observed by lidar. On the other hand, feature $\mathrm{C}$ is not reproduced in this experiment, suggesting that feature B as observed by lidar is a mix of fresh and more aged emissions from Lomé, as well as aged emissions from Cotonou and Accra, while feature $\mathrm{C}$ is almost entirely related to aged pollution from Accra. What is also worth noting is that no emissions from Lagos on 1 and 2 July are observed along the ATR 42 flight track in the TRA_D and TRA_I experiments.

\subsection{Southward transport of the urban plume over the Gulf of Guinea}

Figure 8 shows the structure of the urban pollution plume along four $0.5^{\circ}$ wide north-south transects centered at $0.75^{\circ} \mathrm{W}, 0.25^{\circ} \mathrm{W}, 0.25^{\circ} \mathrm{E}$, and $0.75^{\circ} \mathrm{E}$ on 2 July at 16:00 UTC, i.e. halfway through the ATR 42 flight.

Along the westernmost transect, labelled I in Fig. 1b (centered at $0.75^{\circ} \mathrm{W}$ ), the pollution plume is only composed of emissions from Accra and is lifted off the surface above the ABL (Fig. 8a). Note that no tracer emissions directly occur in this transect, with Accra emissions being contained in transect II, to the east of transect I. As discussed by Knippertz et al. (2017), during the campaign, pollution plumes from 
(a)

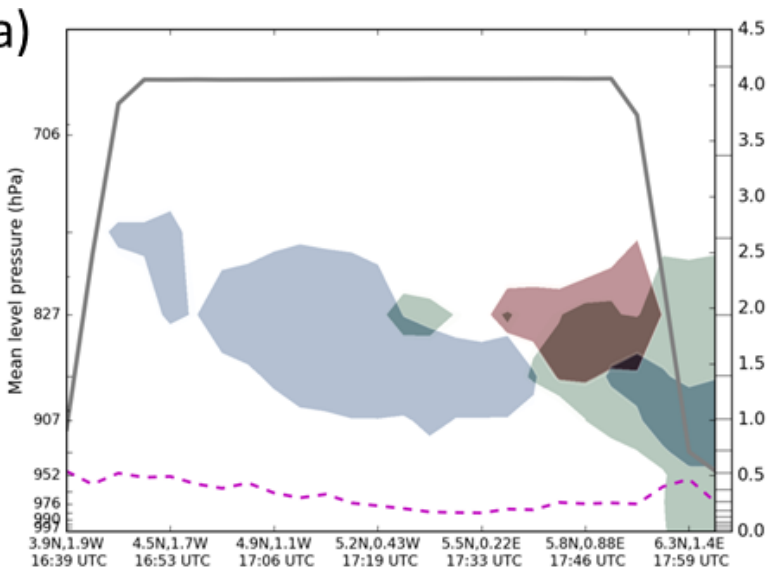

(c)

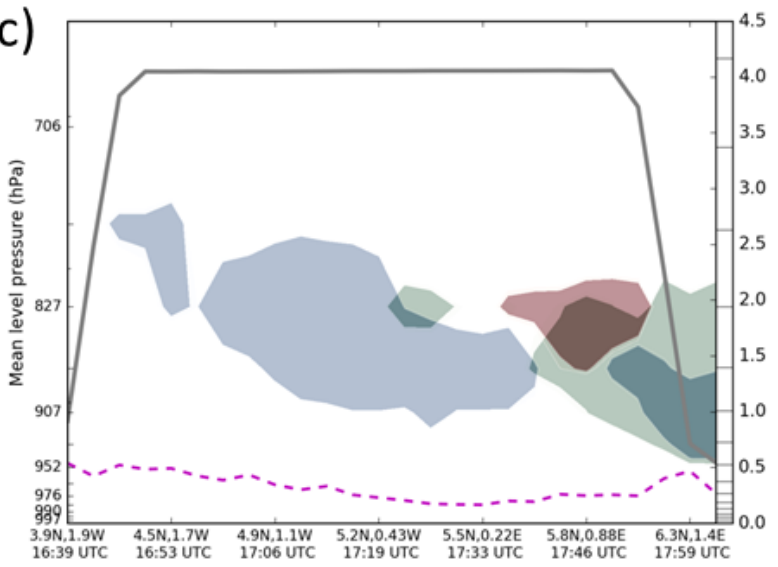

(b)
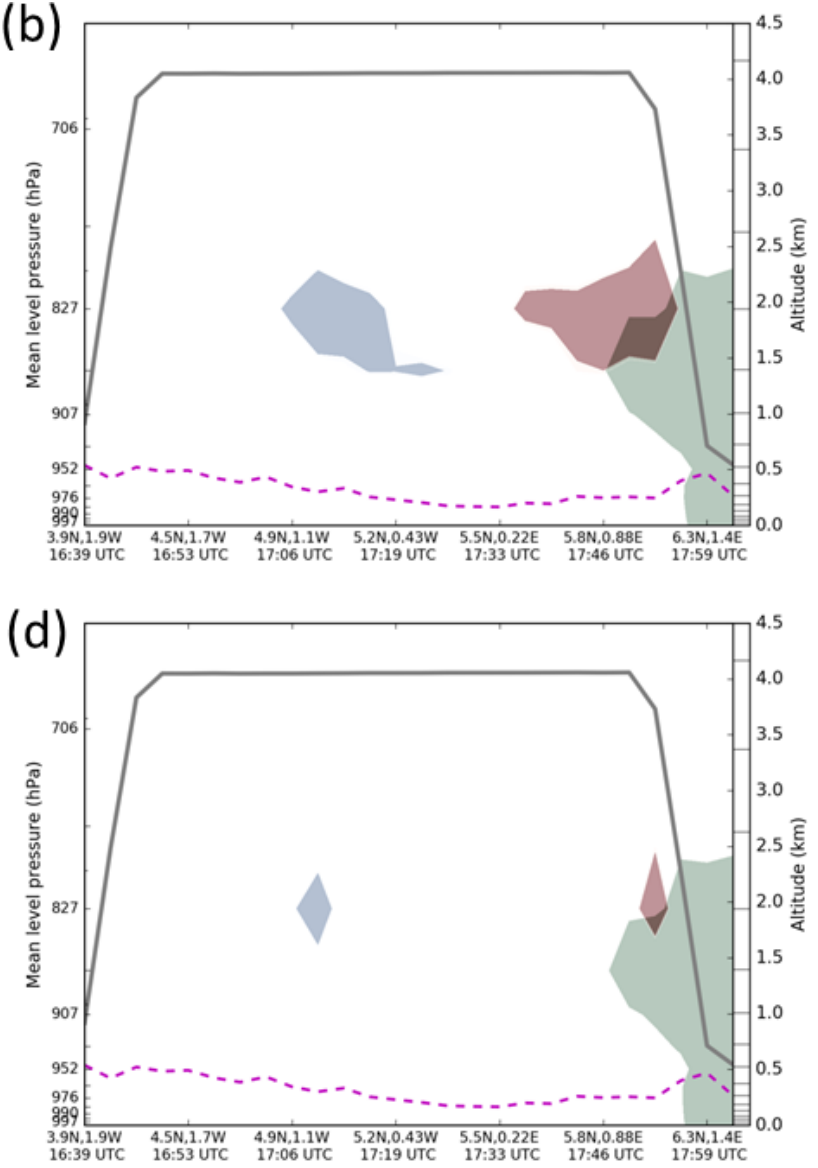

Figure 7. Time-height evolution of tracer concentration (a.u.) below the ATR 42 between 14:00 and 18:00 UTC for the (a) TRA_D12, (b) TRA_I12, (c) TRA_D1, and (d) TRA_D2 experiments (see Sect. 3.2.1 for details). Tracer emissions in Accra, Lomé, and Cotonou appear in blueish, greenish, and reddish colours, respectively. The solid grey line represents the altitude of the aircraft. The dashed magenta line represents the height of the top of the marine ABL from the WRF $2 \mathrm{~km}$ simulation.

coastal cities were mostly directed northeastwards (see their Fig. 19). Hence the tracer plume seen in the experiment on 2 July is associated with transport of tracers emitted on 1 July in the monsoon flow toward the northeast, which are then vertically mixed (due to thermally and mechanically driven turbulence), and westward advection of the tracers by the easterly flow above the monsoon layer. Over the ocean, the plume is seen to extend as far south as $4.7^{\circ} \mathrm{N}$, i.e. the southernmost extension seen on all transects shown in Fig. 8. This is linked to a small equatorward component in the easterly flow.

Along the transect centered at $0.25^{\circ} \mathrm{W}$ (transect II, Fig. 1b), the plume is seen to be in contact with the surface as far north as $6.5^{\circ} \mathrm{N}$ (Fig. 8b). The strong ascent at $6^{\circ} \mathrm{N}$ is related to the presence of the Mampong range in the Ashanti uplands (see Fig. 1b). The presence of the range and the associated upward motion contributes to deep mixing of the plume north of Accra, with the top of the tracer plume reaching $4 \mathrm{~km}$ above the ground level or higher. Strong subsidence is seen north of the Mampong range that mixes tracers down to the surface. Other ascending and subsiding motions are detectable over the Lake Volta area, which could be related to land-lake breeze systems. South of $6^{\circ} \mathrm{N}$, the tracer plume is as deep as along transect I, but does not extend southward over the ocean. Here also, only emissions from Lomé contribute to the pollution plume on 2 July, suggesting that it took $24 \mathrm{~h}$ for these emissions to reach transect II.

The pollution plume along the transect centered at $0.25^{\circ} \mathrm{E}$ (transect III) is structurally similar to the one along transect II, but reaches farther inland $\left(\sim 7.5^{\circ} \mathrm{N}\right.$ at the surface, Fig. $\left.8 \mathrm{c}\right)$ than in transect II, likely due to the gap between the Mampong range and the Akwapim-Togo range, and the flat terrain around Lake Volta. Again, ascending and subsiding motions are detectable over the Lake Volta area that could be related to land-lake breeze systems. Over the ocean, the plume reaches $5.3^{\circ} \mathrm{N}$ at $1.5 \mathrm{~km}$ a.m.s.l. Emissions from Lomé and Cotonou contribute to the upper and southernmost part of the tracer plume along this transect, just north of $5.6^{\circ} \mathrm{N}$.

Finally, along transect IV, the composition of the urban pollution plume is dominated by emissions from Accra, with a small contribution of emissions from Cotonou and Lomé in 


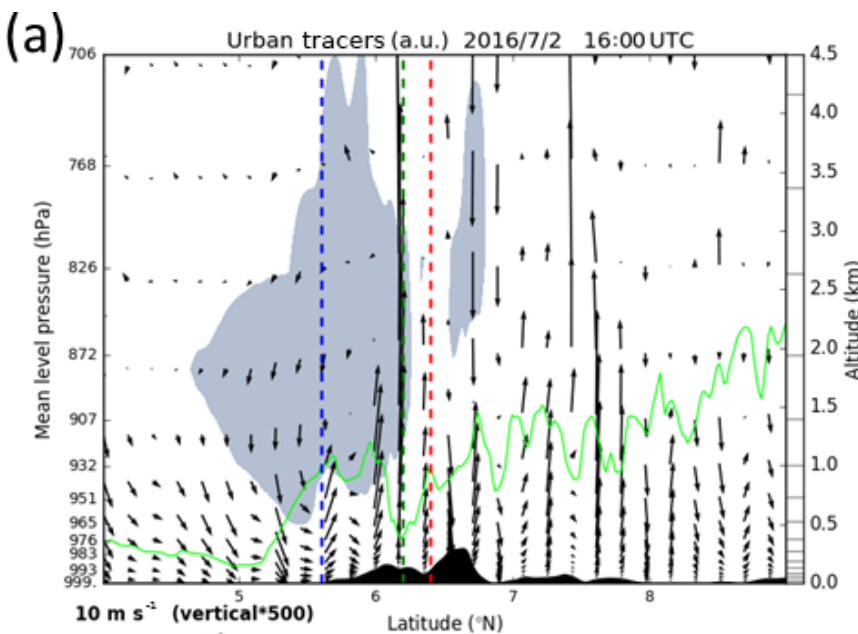

(c)

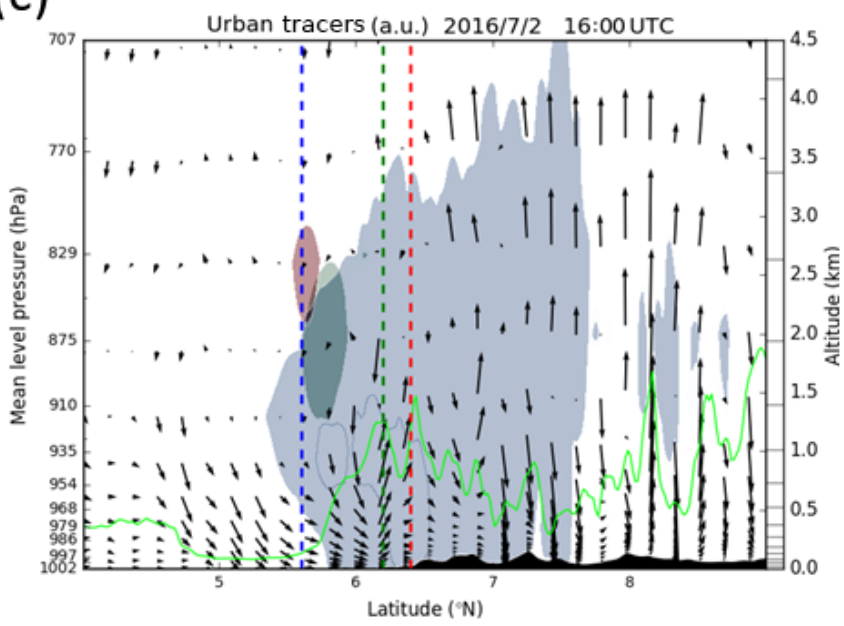

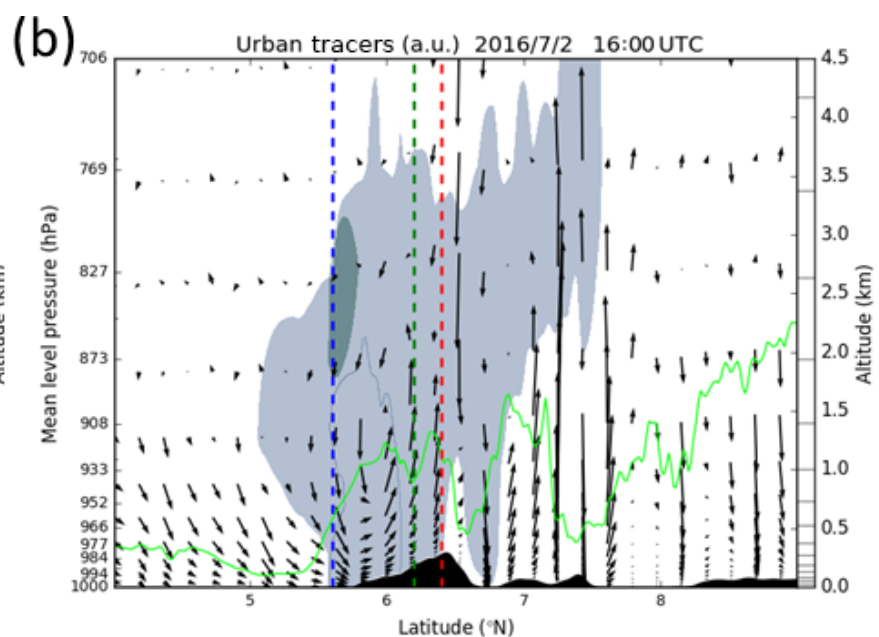

(d)

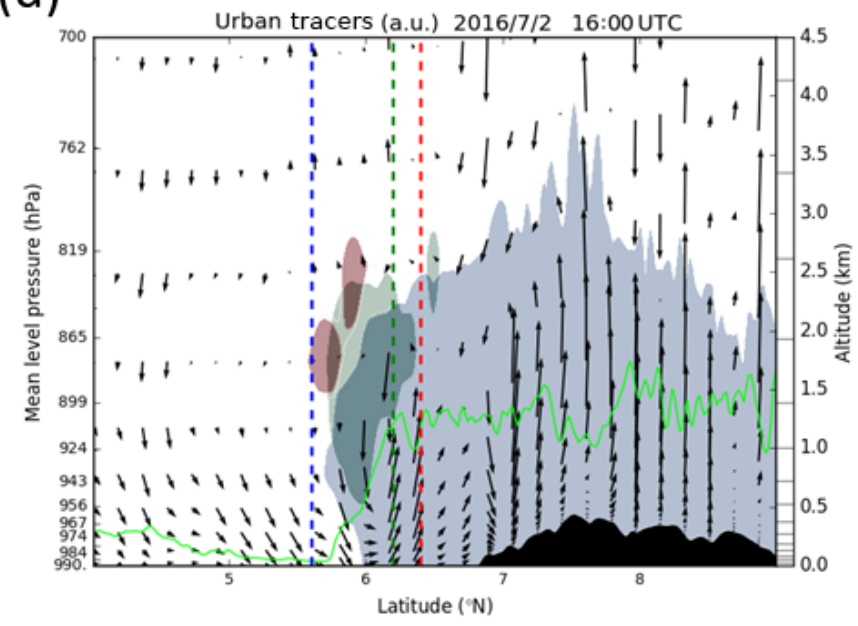

Figure 8. Tracer concentrations (a.u.) from the TRA_D12 experiment (see Sect. 3.2.1 for details) along four 0.5 $5^{\circ}$ wide north-south transects centered on (a) $0.75^{\circ} \mathrm{W}$, (b) $0.25^{\circ} \mathrm{W}$, (c) $0.25^{\circ} \mathrm{E}$, and (d) $0.75^{\circ} \mathrm{E}$ (marked I, II, III, and IV, respectively, in Fig. 1b) at 16:00 UTC. Tracer emissions in Accra, Lomé, and Cotonou appear in blueish, greenish, and reddish colours, respectively, as in Fig. 7. Also shown are meridional-vertical wind vectors in the transects. The green solid line represents the ABL derived from the WRF $2 \mathrm{~km}$ simulation. The vertical dashed lines represent the locations of the cities of Accra (blue), Lomé (green), and Cotonou (red). The orography along the transects is shaded in black.

the southern, uppermost part of the plume because of shortrange westward transport above the monsoon flow (Fig. 8d). The Accra plume is seen to extend from the coastline to as far as $9^{\circ} \mathrm{N}$ and above the depth of the continental ABL, but not as deeply as along other transects with more pronounced orography. The northward extension of the plume suggests that emissions from Accra are transported over Togo along the eastern flank of the Akwapim-Togo range. Over the ocean, the upper part of the plume barely reaches $5.6^{\circ} \mathrm{N}$ at an altitude of $2 \mathrm{~km}$ a.m.s.l.

The differences seen in the structure of the pollution plume obtained from the tracer experiment over land are likely due to interactions between the monsoon flow and the orography just to the north of Accra, namely the southeastnorthwest running Mampong range and the north-south run- ning Akwapim-Togo range to the east of Accra, both bordering Lake Volta (Fig. 1b). In addition to those orographic effects, the monsoon flow transporting the tracers towards the north may also interact with the land-lake breeze system occurring in the summer over Lake Volta (Buchholz et al., 2017; Buchholz, 2017). Addressing the impact of these complex circulations over land on the urban pollution plumes is beyond the scope of this paper.

Strikingly, as in the along-aircraft flight track cross section, emissions from Lagos on 1 and 2 July are never seen in the north-south transects, confirming that they likely do not impact on the air quality in the major coastal cities to the west during this period. Furthermore, the tracer simulations suggest that the pollution plume over SWA related to emissions in the four cities considered here does not extend very 


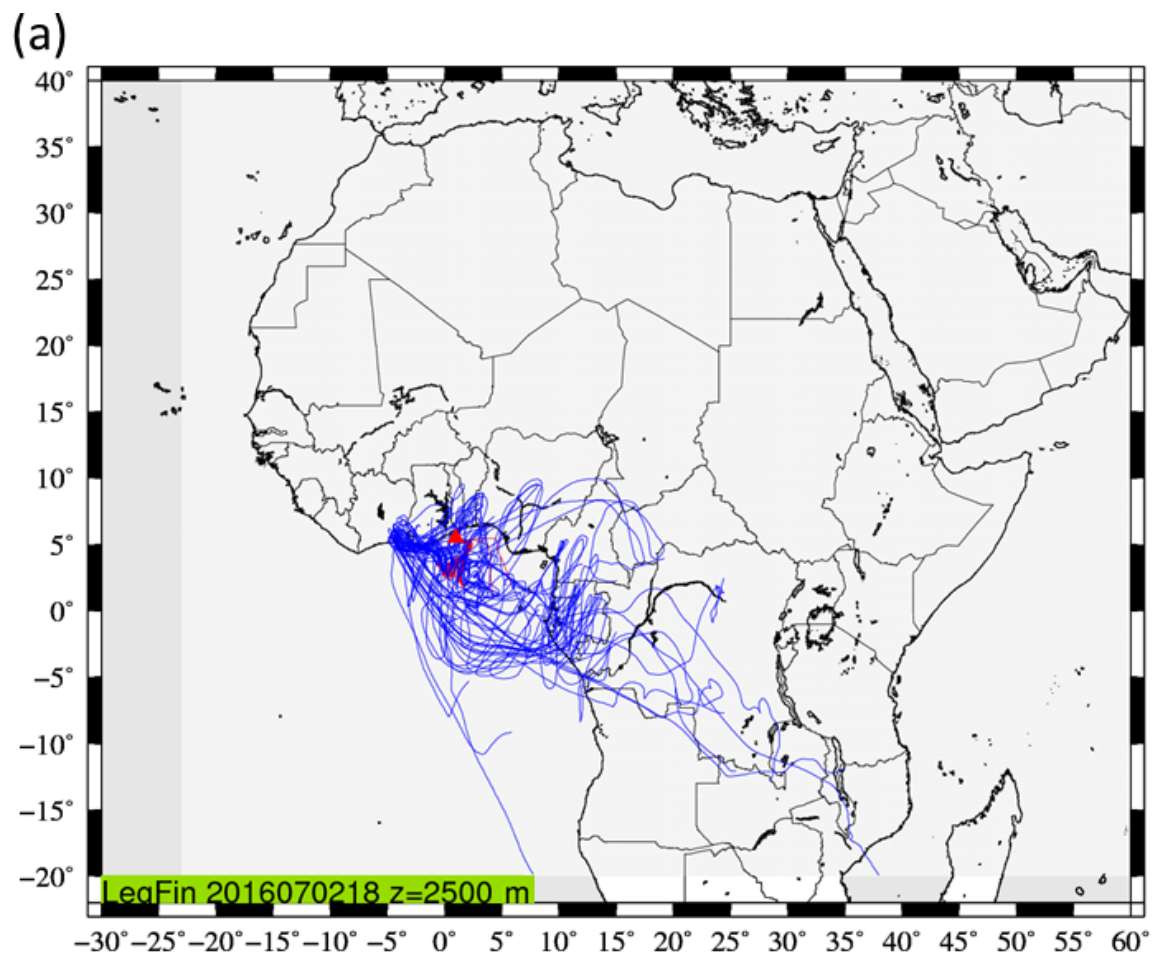

(b)

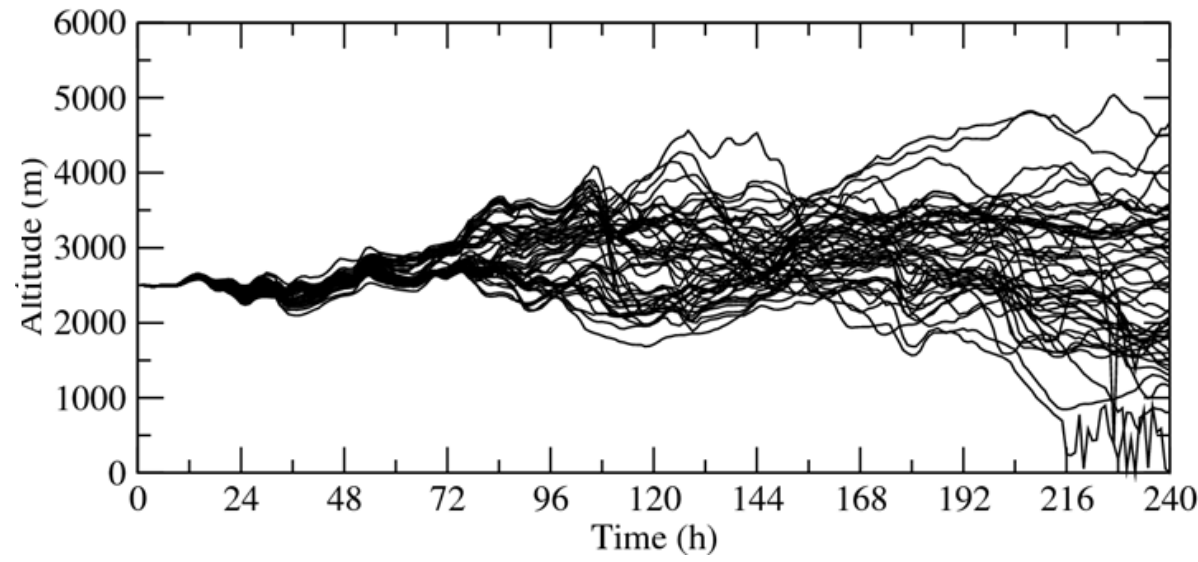

Figure 9. Ten-day CHIMERE-derived backplume ending at $2500 \mathrm{~m}$ a.m.s.1. at $5.5^{\circ} \mathrm{N} / 1^{\circ} \mathrm{E}$ at 17:00 UTC on 2 July 2016 . (a) Individual trajectories are shown as blue solid lines over a political map of Africa with state borders appearing in black. The red triangle indicates the location of the origin of the back-trajectories. (b) Time-height representation of the individual back-trajectories shown in the top panel.

far over the ocean (to $4.7^{\circ} \mathrm{N}$ at most), essentially because they are transported northward within and westward above the marine ABL. Nevertheless, the western part of the Accra pollution plume spreads farther south over the ocean than the eastern part.

\section{Long-range transport of aerosols related to regional-scale dynamics}

To gain insights into the origin of the aerosol layers sampled by the ATR along the elevated leg and observed by lidar (features D and E in Fig. 3), 10-day back-trajectories ending at $2500 \mathrm{~m}$ a.m.s.l. at 17:00 UTC on 2 July are computed using CHIMERE. The backplume associated with feature $\mathrm{D}$ is shown in Fig. 9a (the one associated with feature $\mathrm{E}$ is nearly identical and will not be discussed). The back-trajectories suggest that feature D originates from a broad area including Gabon, Congo, and the Democratic Republic of Congo. Most of the back-trajectories then travel over the Gulf of Guinea towards SWA in the free troposphere (Fig. 9b). Daily mean AOD derived from MODIS and SEVERI observations on 2 July (Fig. 10a) shows large values offshore of Gabon 
(a)

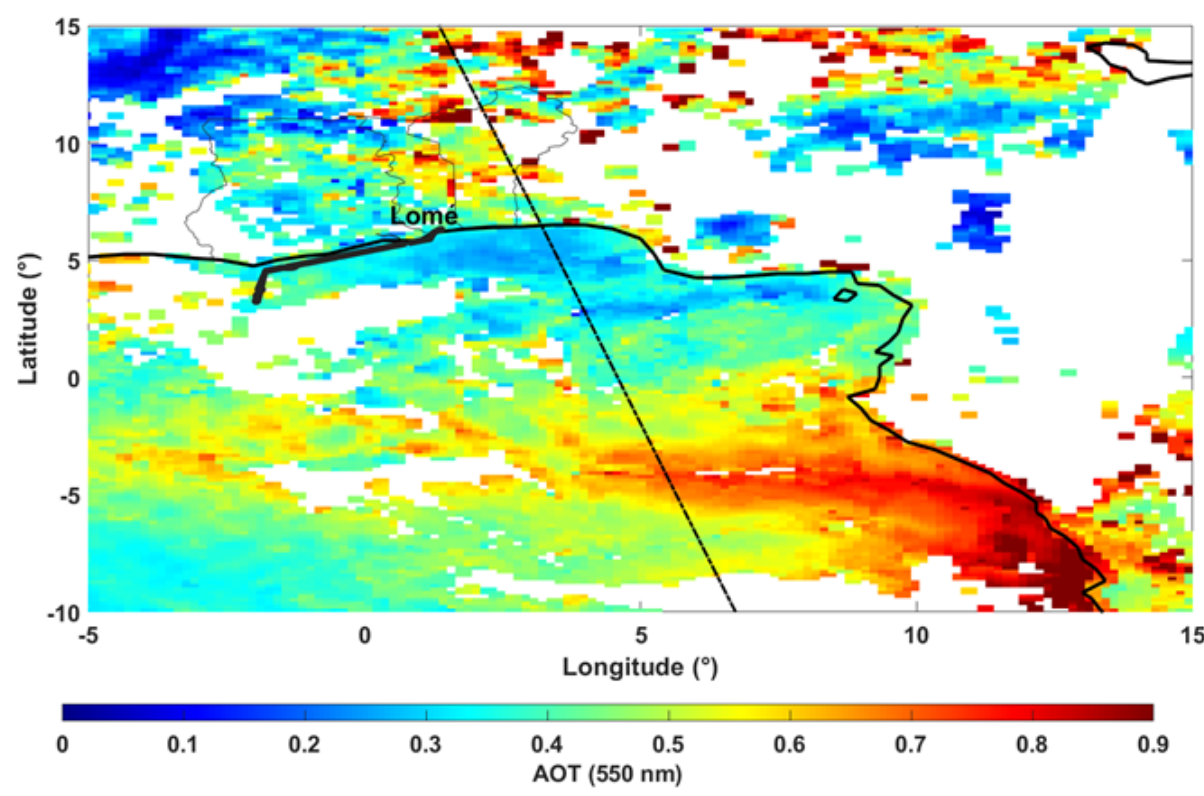

(b)

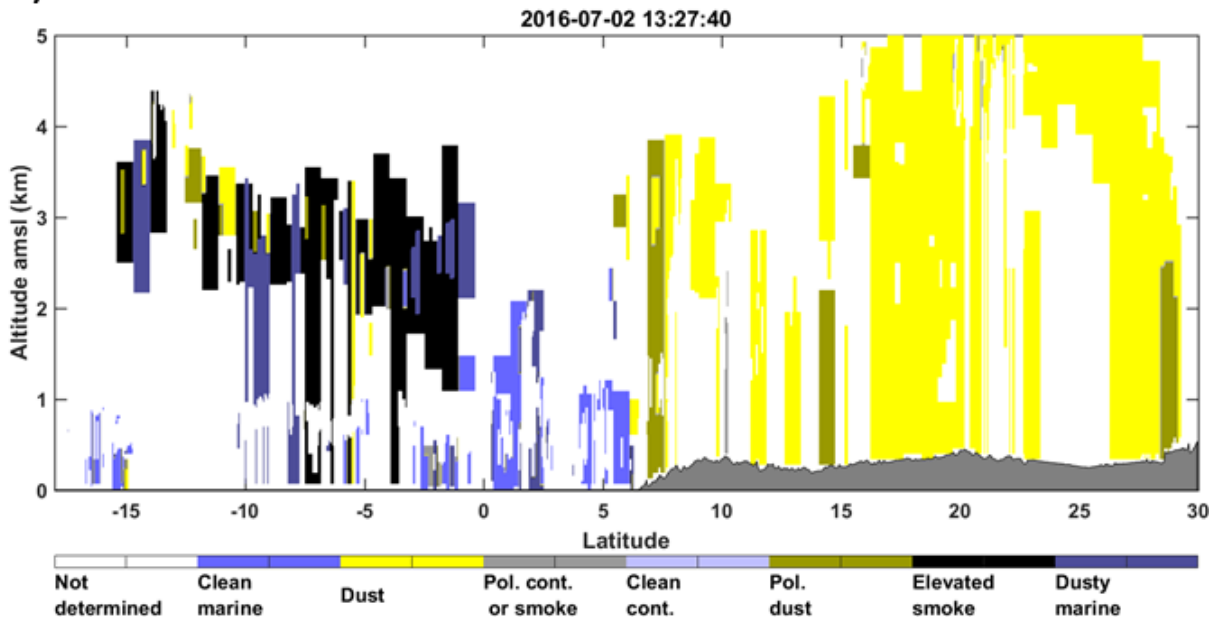

Figure 10. (a) Daily AOD obtained by averaging MODIS Dark target AOD (at 13:25 UTC) and SEVIRI AOD (daily mean) on 2 July 2016. White areas indicate missing data. Country borders of Ghana, Togo, and Benin are shown as thin solid black lines. The straight dashed-dotted line indicates the location of the CALIOP afternoon overpass at 13:27 UTC. The thick solid black line represents the ATR 42 flight track. (b) CALIOP-derived aerosol classification for the afternoon overpass.

and Congo known to be biomass burning aerosol emission hotspots at this time of year (e.g. Menut et al., 2018). This is corroborated by the CAMS biomass burning aerosol forecast at 12:00 UTC (Fig. S4a).

The afternoon CALIOP observations acquired to the east of the ATR 42 flight track across the enhanced AOD feature (see the track in Fig. 10a) indeed classify the aerosols over the ocean as elevated smoke, transported between 1.5 and $4 \mathrm{~km}$ a.m.s.l. (Fig. 10b). The altitude of transport is consistent with that derived from the CHIMERE backplume
(Fig. 9b) as also shown by Menut et al. (2018). Along this transect, dust is observed to almost reach the SWA coastline from the north (Fig. 10b), consistent with the moderate AOD values observed over Togo and Benin (Fig. 10a). Furthermore, the morning ATR 42 flight conducted on 2 July in the region of Savè (Benin, $\sim 8^{\circ} \mathrm{N}$ ) highlighted the presence of dust over northern Benin (Flamant et al., 2018). Interestingly, at the coast $\left(\sim 6^{\circ} \mathrm{N}\right)$, CALIOP shows evidence of polluted dust, possibly resulting from the mixing of dust with anthropogenic emissions from coastal cities. However, 
(a)

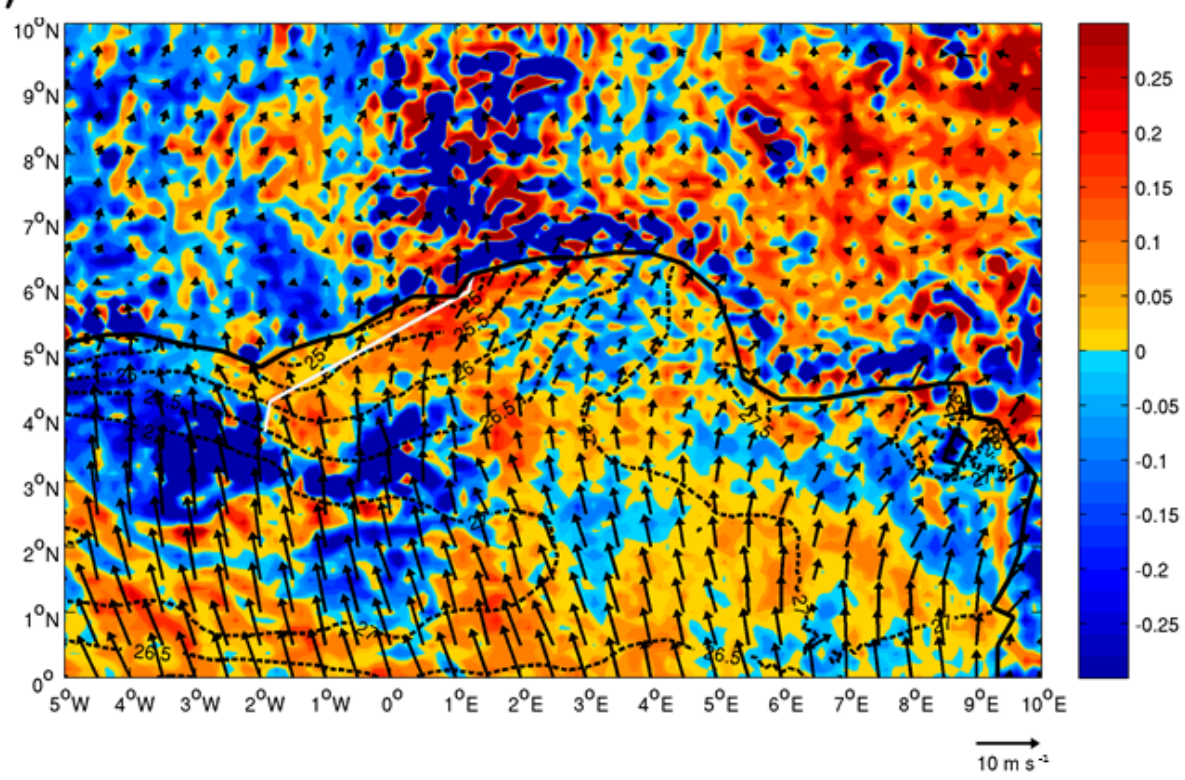

(b)

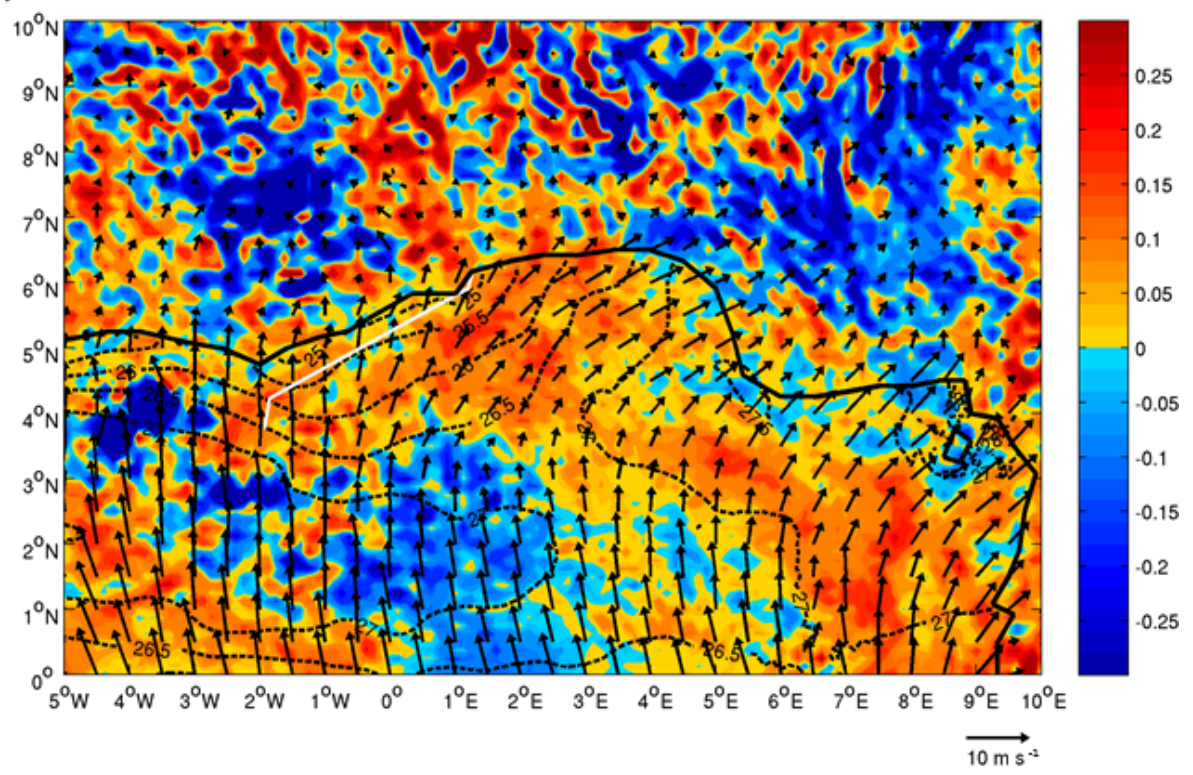

Figure 11. Vertical velocity averaged between 850 and $600 \mathrm{hPa}$ (colour, $\mathrm{Pa} \mathrm{s}^{-1}$ ) with $10 \mathrm{~m}$ winds (vectors) and SST (contours, black dotted lines) from IFS analyses at (a) 12:00 UTC and (b) 18:00 UTC. The thick black line represents the SWA coastline. The straight white line represents the ATR 42 flight track.

the CAMS forecast does not show dust reaching the SWA coast (Fig. S4b).

The backplume and regional-scale dynamics analyses indicate that the upper-level aerosol features D and $\mathrm{E}$ (as observed by lidar) are related to biomass burning over central Africa. In the case of feature D, closer to Lomé, MODIS, SEVIRI, and CALIOP observations suggest the possibility of mixing with dust, which is consistent with the ATR in situ and lidar-related observations.

\section{Coastal circulations: the role of surface temperature} gradients and orography

IFS vertical velocity computed between 850 and $600 \mathrm{hPa}$ (i.e. above the monsoon flow) shows that most of the northern Gulf of Guinea is under the influence of subsiding motion on 2 July at 18:00 UTC (Fig. 11b). Stronger subsidence is seen to the east of the region of operation of the ATR 42 at that time. Strong subsidence is also seen over the eastern part of 
(a)

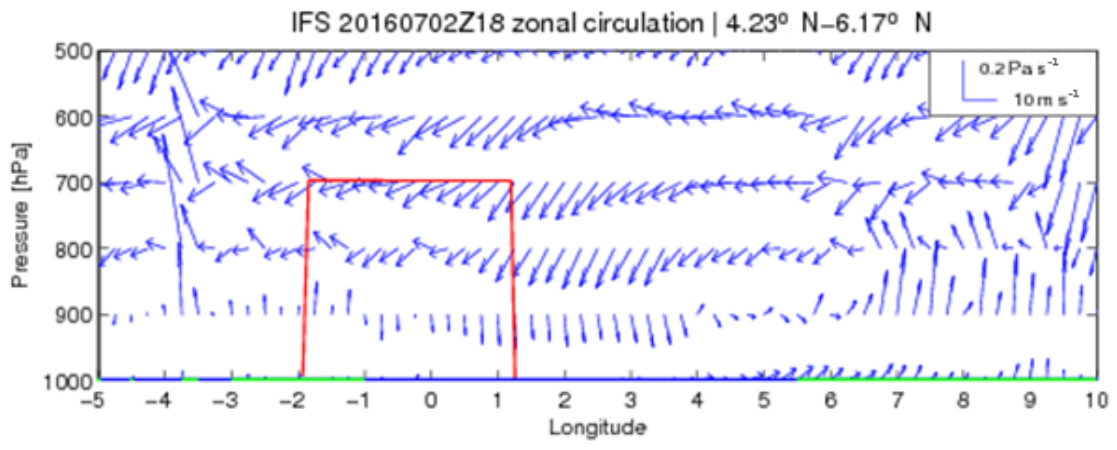

(b)

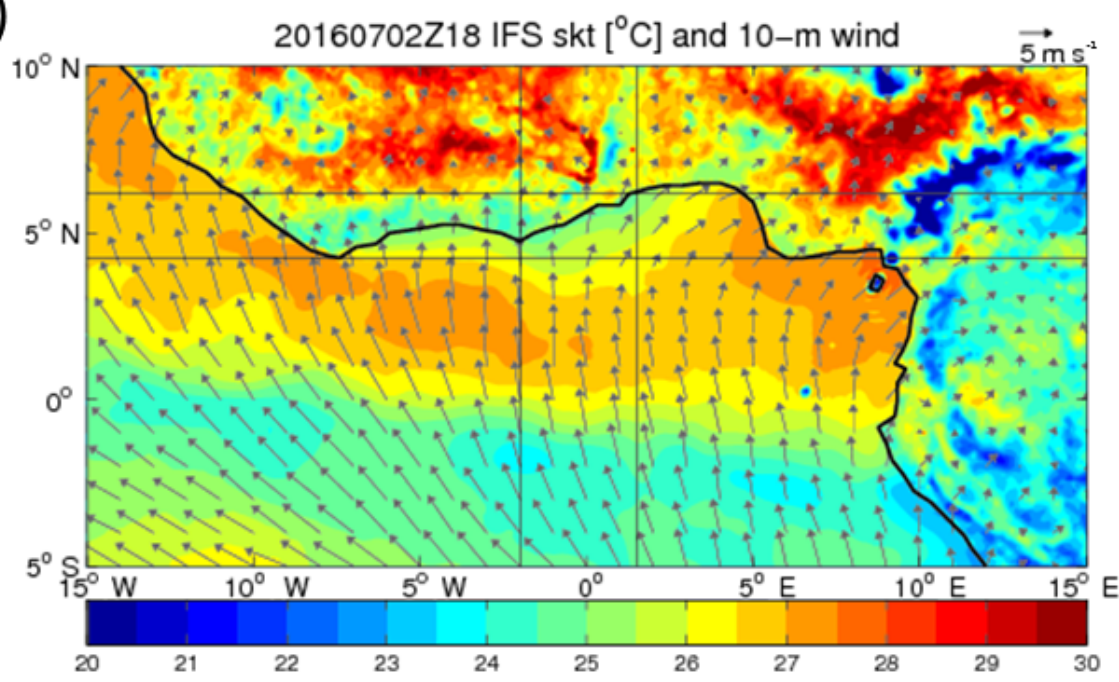

(c)

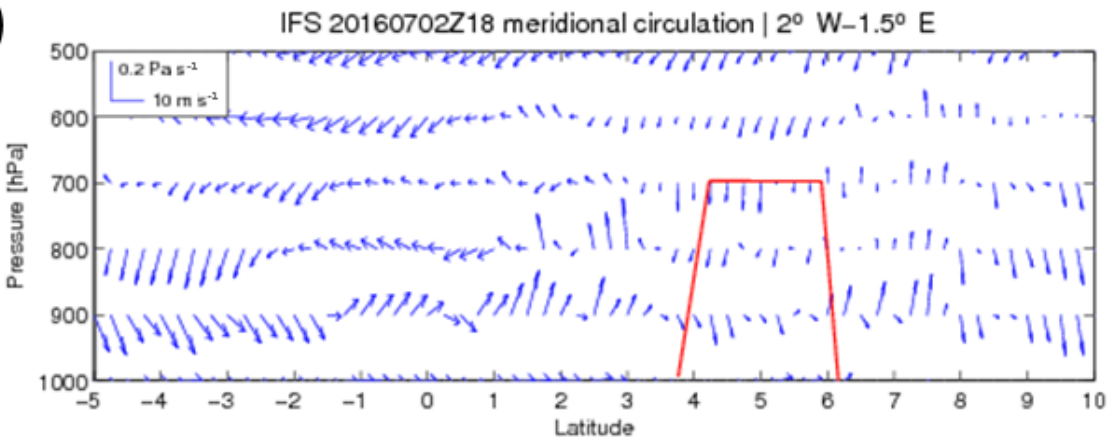

Figure 12. (a) West-east oriented vertical cross section (1000-500 hPa) of zonal-vertical wind vectors from IFS analyses (blue) between $5^{\circ} \mathrm{W}$ and $10^{\circ} \mathrm{E}$ averaged between 4.54 and $6.17^{\circ} \mathrm{N}$ at 18:00 UTC on 2 July 2016. The thick red line is the projection of the ATR 42 aircraft track onto the cross section. The thick green and blue lines at the bottom of the graph indicate the presence of land and ocean, respectively. Surface characteristics are defined based on the dominating surface type in the latitudinal band considered for the average of the wind field. (b) IFS skin temperature (colours) and wind field at $10 \mathrm{~m}$ (vectors) at 18:00 UTC. The former, originally at $0.125^{\circ}$ resolution, has been linearly interpolated onto the Copernicus grid at $5 \mathrm{~km}$ before computing the skin temperature differences between the observations and the model. (c) North-south oriented vertical cross section $(1000-500 \mathrm{hPa})$ of meridional-vertical wind vectors from IFS analyses (blue) between $5^{\circ} \mathrm{S}$ and $10^{\circ} \mathrm{N}$ averaged between $2^{\circ} \mathrm{W}$ and $1.5^{\circ} \mathrm{E}$ at 18:00 UTC. The thick red line is the projection of the ATR 42 aircraft track onto the cross section. Cross sections shown in (a) and (c) are computed in the zonal and meridian windows' delimited east-west and north-south lines, respectively, shown in (b). 
Table 2. Correlation between vertical velocity and land-sea skin temperature gradients at 00:00, 06:00, 12:00, and 18:00 UTC for July 2016. The land-sea zonal skin temperature gradient is computed using a "land box" defined as $6-9^{\circ} \mathrm{E}$ and $4.5-6.5^{\circ} \mathrm{N}$ and a "sea box" defined as $2-5^{\circ} \mathrm{E}$ and $4.5-6.5^{\circ} \mathrm{N}$. The land-sea meridional skin temperature gradient is computed using a "land box" defined as $2^{\circ} \mathrm{W}-2^{\circ} \mathrm{E}$ and $6-8^{\circ} \mathrm{N}$ and a "sea box" defined as $2^{\circ} \mathrm{W}-2^{\circ} \mathrm{E}$ and $3-5^{\circ} \mathrm{N}$. Vertical velocity is averaged in the layer $850-600 \mathrm{hPa}$ over a box defined as $2^{\circ} \mathrm{W}-2^{\circ} \mathrm{E}$ and $4-6^{\circ} \mathrm{N}$. Correlations are computed using vertical velocity and skin temperature gradient indices standardized to 00:00, 06:00, 12:00, and 18:00 UTC means for the month of July 2016. Significant correlations (and their $p$ values) are given in bold.

\begin{tabular}{|c|c|c|c|c|c|}
\hline \multirow[t]{2}{*}{ Zonal cell } & & \multicolumn{4}{|c|}{ Vertical velocity } \\
\hline & & 00:00 UTC & 06:00 UTC & 12:00 UTC & 18:00 UTC \\
\hline \multirow[t]{4}{*}{ Skin temperature gradient } & 00:00 UTC & 0.26 & -0.04 & 0.12 & -0.17 \\
\hline & 06:00 UTC & & -0.08 & 0.09 & 0.11 \\
\hline & 12:00 UTC & & & 0.02 & $0.53(p=0.002)$ \\
\hline & 18:00 UTC & & & & $0.46(p=0.01)$ \\
\hline \multirow[t]{2}{*}{ Meridional cell } & & \multicolumn{4}{|c|}{ Vertical velocity } \\
\hline & & 00:00 UTC & 06:00 UTC & 12:00 UTC & 18:00 UTC \\
\hline \multirow[t]{4}{*}{ Skin temperature gradient } & 00:00 UTC & 0.07 & -0.22 & 0.06 & -0.07 \\
\hline & 06:00 UTC & & -0.01 & \multirow{3}{*}{$\begin{array}{r}0.01 \\
\mathbf{0 . 3 4}(\boldsymbol{p}=\mathbf{0 . 0 6})\end{array}$} & -0.06 \\
\hline & 12:00 UTC & & & & -0.24 \\
\hline & 18:00 UTC & & & & 0.20 \\
\hline
\end{tabular}

the ATR 42 flight track at 12:00 UTC (Fig. 11a). However, at 12:00 UTC, the eastern part of the northern Gulf of Guinea is characterized by upward motion, possibly in relationship with the SST gradient (cold water to the west linked with the coastal upwelling and warmer waters to the east in the Niger Delta region). The signature of the sea breeze is also visible inland in the IFS analysis at 12:00 UTC (Fig. 11a) in the form of a line of strong ascendance running parallel to the coastline.

At the regional scale, IFS analyses show the existence of a marked surface temperature difference between the ocean and the continent at 12:00 UTC (Fig. S5d) because of the high insolation across SWA as noted in Sect. 2. The surface temperature gradient across the coast creates shallow overturning circulations as evidenced by IFS analyses at 18:00 UTC (Fig. 12). A well-defined closed zonal cell can be identified below $600 \mathrm{hPa}$ around $5^{\circ} \mathrm{N}$ and between 0 and $8^{\circ} \mathrm{E}$ (Fig. 12a), while a well-defined meridional cell is seen around $0^{\circ} \mathrm{E}$ between 3 and $8^{\circ} \mathrm{N}$ (Fig. 12c). It is worth noting that the overturning circulations are most intense and better defined at 18:00 UTC than at 12:00 UTC (compare Fig. 12a with Fig. S5c for the zonal cell), even though the surface temperature difference across the coast is weaker (compare Fig. 12b with Fig. S5d). The overturning circulation exhibits a strong diurnal cycle (Fig. S5), which is driven by the surface temperatures over land. The quality of IFS skin temperature during the day was verified against observed landsurface temperature observations (the so-called Copernicus product; see Fig. S6). In spite of a systematic bias of the order of $2{ }^{\circ} \mathrm{C}$ over land, IFS skin temperature analyses are seen to be consistent (in terms of spatio-temporal distribution) with the Copernicus product (Fig. S6). This gives us confidence that the overturning circulations exist and contribute to enhancing subsidence over the Gulf of Guinea. Furthermore, we have conducted an analysis of the correlation between the land-sea skin temperature gradients associated with both the zonal and meridian cells and the vertical velocity over the Gulf of Guinea at different times of day for the whole of July 2016, based on IFS data (Table 2). The analysis shows that the zonal land-sea skin temperature gradient at 12:00 and 18:00 UTC is significantly correlated with vertical velocity at 18:00 UTC, with values around 0.5 . Hence, the overturning cells evidenced on 2 July appear to be persistent features over the Gulf of Guinea, at least in post-monsoon onset conditions. On the other hand, the meridional land-sea skin temperature gradient at 12:00 UTC is correlated (0.34) with vertical velocity at 12:00 UTC, possibly due to the presence of orography as discussed in the following. The meridional gradient of skin temperature between the sea and the land is an indicator of the pressure difference and thus drives the intensity of the southerly flow associated with the land-sea breeze. When the southerly flow impinges on the low terrain over SWA, as it progresses over the continent, enhanced vertical motion is generated.

In addition to the subsidence generated at the regional scale by the land-sea temperature gradient, the interaction of the monsoon flow with the orography over Ghana and Togo is responsible for more local coastal circulations. This interaction is reflected in the vertical velocity anomaly simulated with WRF along the westernmost and easternmost transects in Fig. 1b (transects I and IV, respectively). The anomalies are computed with respect to the average vertical velocity between $1^{\circ} \mathrm{W}$ and $1^{\circ} \mathrm{E}$. Figure 13 shows that in the region where orography is more pronounced (i.e. to the west), the 

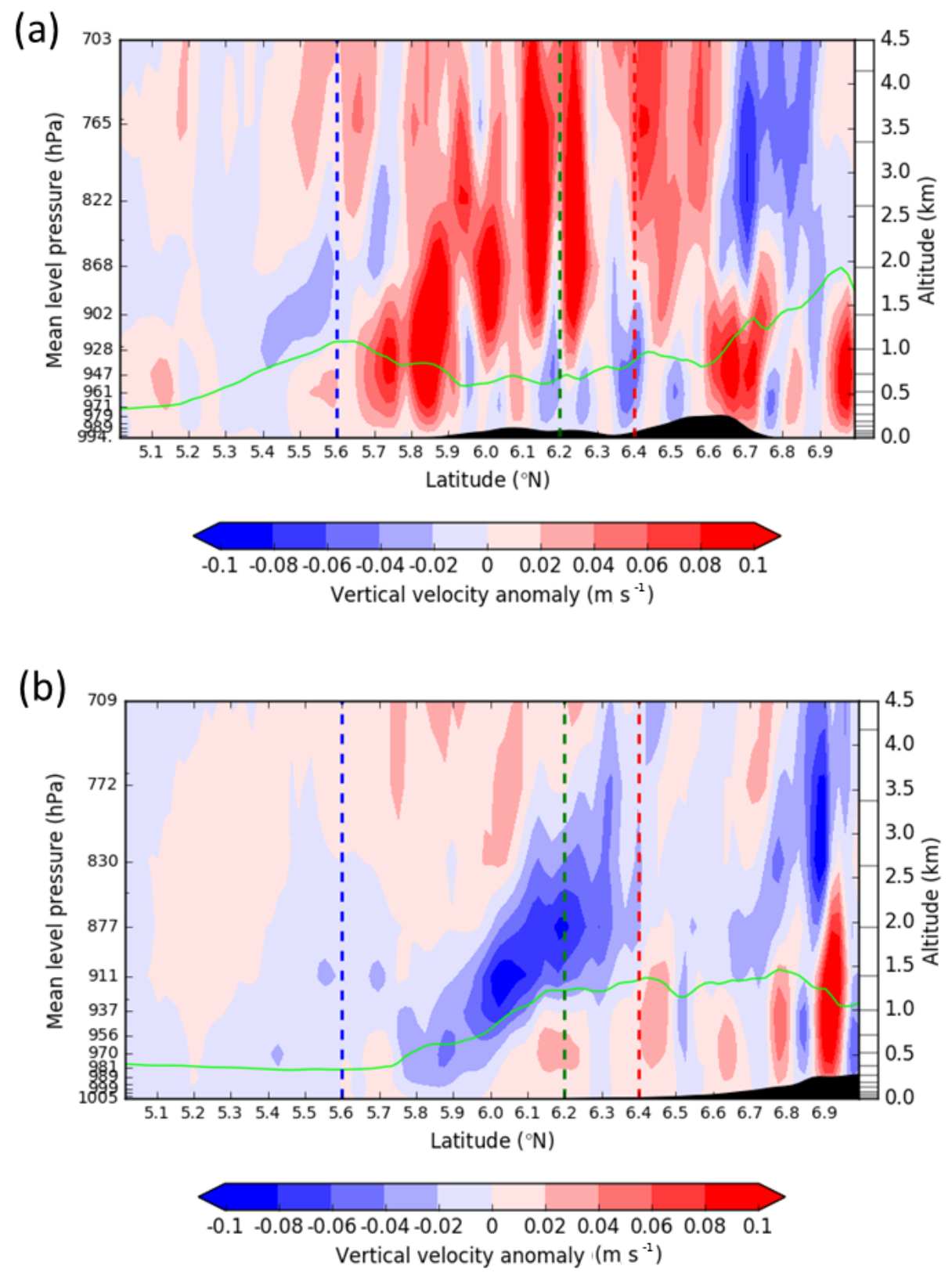

Figure 13. Vertical velocity anomaly along (a) the westernmost transect shown in Fig. 1b (transect I) and (b) the easternmost transect shown in Fig. $1 \mathrm{~b}$ (transect IV), from the WRF $2 \mathrm{~km}$ simulation. The anomalies are computed with respect to the average vertical velocity between $1^{\circ} \mathrm{W}$ and $1^{\circ} \mathrm{E}$.

vertical velocity anomaly is positive, while it is negative to the east where orography is less marked (compare Fig. 13a and $b$ ). As a result, the eastern region of ATR 42 operation on 2 July is under the influence of a strong subsiding motion. This subsiding motion suppresses low-level cloudiness near Lomé and is key to the interpretation of the ATR 42 lidar observations along the track regarding the slanting of the elevated aerosol layers and, possibly, the thinning of the marine ABL towards the eastern end of the aircraft track, together with an additional effect of colder SSTs.
MODIS observations show the existence of an SST dipole across the northern part of the Gulf of Guinea (Figs. S7 and 11), between the coastal upwelling offshore of Lomé and Accra (SSTs of the order of $26^{\circ} \mathrm{C}$ ) and the warmer SST to the east in the Bight of Bonny (offshore Nigeria, where SSTs of the order of $28^{\circ} \mathrm{C}$ are generally observed). Even though this SST dipole may also generate a secondary circulation over the Gulf of Guinea (e.g. around $900-800 \mathrm{hPa}$ and between 0 and $1^{\circ} \mathrm{E}$ in Fig. S5c), it is very likely that the lower tropospheric dynamics in the region of operation of the aircraft 
are dominated by the monsoon dynamics to the first order and by the sea-land surface temperature gradient at the regional scale.

\section{Summary and conclusions}

In this study, detailed aircraft observations on 2 July 2016 and accompanying model simulations were used to analyse the distribution of aerosols over the Gulf of Guinea and its meteorological causes. We show that land-sea surface temperature gradients between the northern part of the Gulf of Guinea and the continent as well as orography over Ghana and Togo play important roles for the distribution of aerosols and gases over coastal SWA on that day. The former creates large-scale subsidence conditions over the northern part of the Gulf of Guinea through the generation of zonal and meridional overturning circulations below $600 \mathrm{hPa}$, with the downward branch of the circulation around $0^{\circ} \mathrm{E}$ over the ocean. The latter generates enhanced subsidence over the eastern part of the ATR 42 operation area, near Lomé and Accra. Together this leads to a west-east tilting of the aerosol layers (that can be considered passive tracers of the dynamics) along the flight track. The ATR 42 sampled remotely and in situ the complex aerosol layering occurring between 2.5 and $3.2 \mathrm{~km}$ a.m.s.l. over the Gulf of Guinea as a result of long-range transport of dust (from the northeast) and biomass burning aerosol from the south (feature E in Fig. 3) and the mixing between these (feature D).

The orography-forced circulation also has an influence on the structure of the urban pollution plumes from Accra, Lomé, and Cotonou as assessed from airborne lidar measurements on 2 July and numerical passive tracer experiments using the WRF and CHIMERE models. When accounting for the relative size of the emitting cities along the coast $(\sim 2$ times more emissions in Accra than in Lomé), we find that the tracer experiment designed to include emissions from 1 and 2 July is the most realistic in reproducing the lidar observations. The analysis shows that (a) the large pollution plumes observed at the coast up to $1.5 \mathrm{~km}$ (features A and B) are essentially related to emissions in the Lomé area from both 1 and 2 July, with a moderate contribution from Accra and Cotonou, (b) the elevated plume over the northern part of the Gulf of Guinea (feature C) is related to emissions from Accra exclusively from the day before the ATR 42 flight (i.e. 1 July) and these clearly dominate the composition of the tracer plume in the region covered by the flight track on 2 July, (c) given the general direction of the monsoon flow, Lagos emissions (taken to be 13 times that of Cotonou) do not appear to have affected the atmospheric composition west of Cotonou, where our airborne observations were gathered, as also shown by Deroubaix et al. (2018) in post-monsoon onset conditions, and (d) the tracer plumes do not extend very far over the ocean during the short period under scrutiny, mostly because they are transported north- ward within the marine ABL and westward above it so that their extent is controlled by the equatorward component in the mostly easterly flow as modulated by synoptic-scale disturbances (Knippertz et al., 2017).

The unique combination of in situ and remote sensing observations acquired over the Gulf of Guinea during the 2 July 2016 OLACTA flight together with global and regional model simulations revealed in detail the impact of the complex atmospheric circulation at the coast on the aerosol composition and distribution over the northern Gulf of Guinea. We show that on hot, cloud-free summer days such as 2 July, the western Gulf of Benin is a place favourable for subsidence in the afternoon due to three factors, namely cool SSTs, zonal overturning connected with the Niger Delta region, and meridional overturning connected with the main West African landmass, anchored geographically at the Mampong and Akwapim-Togo ranges. We also show that the overturning cells are robust features of the atmospheric circulation over the Gulf of Guinea in July 2016. To the best of the authors' knowledge such features have not been documented in the literature to date. Still, one should keep in mind that the mechanisms described in detail are based on a unique dataset. Even though we have highlighted the fact that some of the key dynamical features are persistent during July 2016, and hence not just representative of 2 July, caution should be exercised when drawing more general conclusions regarding the role of observed circulation in aerosol redistribution in this region.

Further research will be dedicated to enhancing our understanding of the complex interactions between the monsoon flow and the orography north of major coastal cities as well as the land-sea and land-lake breezes, and their impact on the dispersion of pollution emissions from major coastal cities in SWA. Future research will also be conducted to assess the long-term impact of the land-sea surface temperature gradient (and related shallow overturning circulation) on the distribution of aerosols over the northern Gulf of Guinea.

Data availability. The aircraft and radiosonde data used here can be accessed using the DACCIWA database at http://baobab.sedoo. fr/DACCIWA/ (Brissebrat et al., 2017). The tracer simulations discussed in this paper are also available in the database. An embargo period of 2 years after the upload applies. After that, external users can access the data in the same way as DACCIWA participants before that time. Before the end of the embargo period, external users can request the release of individual datasets. It is planned for DACCIWA data to get DOIs, but this has not been realized for all datasets yet. 


\section{Appendix A: The ULICE lidar characteristics and data processing}

For the two channels of the lidar (indexed 1 and 2), the apparent backscatter coefficient ( $\mathrm{ABC}, \beta_{\mathrm{app}}$ ) is given by

$$
\begin{aligned}
\beta_{\text {app }}^{1(2)}(r)= & C^{1(2)} \cdot\left(\beta_{\mathrm{m}}^{1(2)}(r)+\beta_{\mathrm{a}}^{1(2)}(r)\right) \\
& \cdot \exp \left(-2 \cdot \int_{0}^{r} \alpha_{\mathrm{a}}\left(r^{\prime}\right) \cdot \mathrm{d} r^{\prime}\right),
\end{aligned}
$$

where $\beta_{\mathrm{m}}$ and $\beta_{\mathrm{a}}$ are the backscatter coefficients for the molecular and aerosol contributions, respectively; $\alpha_{\mathrm{a}}$ is the aerosol extinction coefficient; $C^{1(2)}$ are the instrumental constants for each channel. The total $\mathrm{ABC}$ is given by

$\beta_{\mathrm{app}}(r)=\frac{\beta_{\mathrm{app}}^{1}(r) \cdot(1+\operatorname{VDR}(r))}{C^{1} \cdot\left(T_{1}^{/ /}+T_{1}^{\perp} \cdot \operatorname{VDR}(r)\right)}$,

where $T_{i}^{/ /}$and $T_{i}^{\perp}$ are the transmissions of the copolarization and cross-polarization contributions of the lidar polarized plate $i$, respectively. The VDR is thus given by the equation

$\operatorname{VDR}(r) \approx \frac{T_{1}^{/ /} \cdot \beta_{\mathrm{app}}^{2}(r)(r)}{R_{\mathrm{c}} \cdot \beta_{\mathrm{app}}^{1}(r)(r)}-\left(1-T_{1}^{/ /}\right) \cdot\left(1-T_{2}^{/ /}\right)$.
The apparent scattering ratio (ASR, denoted $R_{\text {app }}$ ) is expressed as

$R_{\text {app }}(r)=\beta_{\text {app }}(r) / \beta_{\mathrm{m}}^{/ /}(r)$.

As also shown by Chazette et al. (2012), the cross-calibration coefficient $R_{\mathrm{c}}=C^{2} / C^{1}$ can be assessed by normalizing the lidar signals obtained in aerosol-free conditions, assuming the molecular VDR to be equal to $0.3945 \%$ at $355 \mathrm{~nm}$, following Collis and Russel (1976). The dominant error source is the characterization of the plate transmission on the optical bench, which leads to a relative error close to $8 \%$ on the VDR (Chazette et al., 2012). During the DACCIWA field campaign, all lidar measurements were conducted within aerosol layers and therefore we had to use measurements performed just before the campaign during flight tests above the Mediterranean for assessing $R_{\mathrm{c}}$. During the flight over the Mediterranean, the ATR 42 was flying at an altitude of $6.3 \mathrm{~km}$ a.m.s.l., with ULICE lidar data acquired in the nadir pointing mode between 0 and $6 \mathrm{~km}$ a.m.s.l. The calibration was performed using lidar data acquired well above any aerosol layers, i.e. between 5 and $6 \mathrm{~km}$ a.m.s.l., where the lidar backscatter is only sensitive to the molecular background signal.

Table A1. Summary of ULICE lidar characteristics.

\begin{tabular}{ll}
\hline ULICE lidar & Characteristics \\
\hline Emitter (laser) & Quantel Centurion, diode-pumped, air cooled \\
& $6.5 \mathrm{~mJ}, 8 \mathrm{~ns}, 100 \mathrm{~Hz} @ 354.7 \mathrm{~nm}$ \\
Laser divergence & $<0.1 \mathrm{mrad}$ \\
Output beam & Eyesafe $\sim 40 \times 30 \mathrm{~mm}$ beam, tunable 0 to 40 mrad divergence with Altechna \\
& Motex expander $\left(\mathrm{at} 1 / e^{2}\right.$ ) \\
Receiver & Two channels with the cross-polarizations \\
Telescope & Refractive, $150 \mathrm{~mm}$ diameter, $280 \mathrm{~mm}$ effective focal length \\
Field of view & $\sim 3$ mrad \\
Filtering & Narrow-band filters $(200$ pm) \\
Detection & Hamamatsu H10721 photo-multiplier tubes. \\
Detection mode & Analogue \\
Data acquisition & 12 bits, $200 \mathrm{MHz}$ sampling, two-channel NI-5124 digitizer manufactured by the \\
& National Instruments Company. \\
Vertical sampling Native After data processing & $0.75 \mathrm{~m}$ \\
& $15-30 \mathrm{~m}$ \\
Weight of the optical head & $\sim 20 \mathrm{~kg}$ \\
Weight of the electronics & $\sim 10 \mathrm{~kg}$ \\
Consumption & $350 \mathrm{~W}$ at $24-28 \mathrm{~V}$ DC \\
\hline
\end{tabular}




\section{The Supplement related to this article is available online at https://doi.org/10.5194/acp-18-12363-2018- supplement.}

Author contributions. CF conducted the analysis of the data as well as wrote the paper and selected the figures. AD and LM conducted the WRF/CHIMERE simulation and produced the associated relevant figures. PC and JT processed the ULICE lidar data. PC also created the figures showing CALIOP/MODIS/SEVIRI observations. MG provided the figures showing ECMWF charts as well as Copernicus LST data. Together with PK and AHF, he provided expertise on the analysis of such data for identifying shallow overturning circulations. GdC and RM provided expertise on air-sea interaction processes over the Gulf of Guinea area. JB, CD, PR, RD, TB and AS contributed to the acquisition and the processing of the aerosol data gathered on the ATR42 during the flight on 2 July 2016. AC, $\mathrm{PD}, \mathrm{JD}$ and MR contributed to the acquisition and the processing of the gas-phase chemistry data gathered on the ATR42 during the flight. All co-authors contributed to the data analysis.

Competing interests. The authors declare that they have no conflict of interest.

Special issue statement. This article is part of the special issue "Results of the project "Dynamics-aerosol-chemistry-cloud interactions in West Africa" (DACCIWA) (ACP/AMT inter-journal SI)". It is not associated with a conference.

Acknowledgements. The DACCIWA project has received funding from the European Union Seventh Framework Programme (FP7/2007-2013) under grant agreement no. 603502. The European Facility for Airborne Research (EUFAR, http://www.eufar.net/, last access: 16 August 2018) also supported the project through the funding of Transnational Activity project OLACTA. The Centre National d'Etudes Spatiales (CNES) provided financial support for the operation of the ULICE lidar. The personnel of the Service des Avions Français Instrumentés pour la Recherche en Environnement (SAFIRE, a joint entity of CNRS, Météo-France, and CNES, and operator of the ATR 42) are thanked for their support. Marco Gaetani has been supported by the LABEX project funded by the Agence Nationale de la Recherche (French National Research Agency, grant ANR-10-LABX-18-01). The authors would like to thank Bruno Piguet (CNRM) for his support in the data acquisition and processing. The authors would also like to thank Gregor Pante (KIT) for providing IFS data, as well as Hugh Coe, Sophie Haslett, and Jonathan Taylor (University of Manchester) for helpful discussions. The authors are thankful to the two anonymous referees whose comments helped improve the overall quality of the paper. MODIS data were made available via the Geospatial Interactive Online Visualization ANd aNalysis interface (https://giovanni.gsfc.nasa.gov/giovanni/, last access: 16 August 2018).
Edited by: Susan van den Heever

Reviewed by: two anonymous referees

\section{References}

Anderson, T. L. and Ogren, J. A.: Determining aerosol radiative properties using the TSI 3563 integrating nephelometer, Aerosol Sci. Tech., 29, 57-69, 1998.

Bennouna, Y. S., de Leeuw, G., Piazzola, J., and KusmierczykMichulec, J.: Aerosol remote sensing over the ocean using MSG-SEVIRI visible images, J. Geophys. Res., 114, D23203, https://doi.org/10.1029/2008JD011615, 2009.

Bergstrom, R. W., Pilewskie, P., Russell, P. B., Redemann, J., Bond, T. C., Quinn, P. K., and Sierau, B.: Spectral absorption properties of atmospheric aerosols, Atmos. Chem. Phys., 7, 5937-5943, https://doi.org/10.5194/acp-7-5937-2007, 2007.

Bond, T. C., Anderson, T. L., and Campbell, D.: Calibration and intercomparison of filter-based measurements of visible light absorption by aerosols, Aerosol Sci. Tech., 30, 582-600, 1999.

Brissebrat, G., Belmahfoud, N., Cloché, S., Ferré, H., Fleury, L., Mière, A., and Ramage, K.: The BAOBAB data portal and DACCIWA database, 19th EGU General Assembly, EGU2017, 23-28 April, 2017, Vienna, Austria, p. 4685, available at: http://baobab. sedoo.fr/DACCIWA/ (last access: 16 August 2018), 2017.

Brito, J., Freney, E., Dominutti, P., Borbon, A., Haslett, S. L., Batenburg, A. M., Colomb, A., Dupuy, R., Denjean, C., Burnet, F., Bourriane, T., Deroubaix, A., Sellegri, K., Borrmann, S., Coe, H., Flamant, C., Knippertz, P., and Schwarzenboeck, A.: Assessing the role of anthropogenic and biogenic sources on $\mathrm{PM}_{1}$ over southern West Africa using aircraft measurements, Atmos. Chem. Phys., 18, 757-772, https://doi.org/10.5194/acp-18-7572018, 2018.

Buchholz, M., Fink, A. H., Knippertz, P., and Yorke, C.: Impacts of the land-lake breeze of the Volta reservoir on the diurnal cycle of cloudiness and precipitation, EGU General Assembly, Vienna, Austria, 23-28 April 2017, 2017.

Buchholz, M. A.: The influence of Lake Volta on weather and climate, Karlsruhe Institute of Technology Master Thesis, available at: http://www.imk-tro.kit.edu/download/Masterarbeit_Marcel_ Buchholz.pdf, 2017 (in German).

Burton, S. P., Hair, J. W., Kahnert, M., Ferrare, R. A., Hostetler, C. A., Cook, A. L., Harper, D. B., Berkoff, T. A., Seaman, S T., Collins, J. E., Fenn, M. A., and Rogers, R. R.: Observations of the spectral dependence of linear particle depolarization ratio of aerosols using NASA Langley airborne High Spectral Resolution Lidar, Atmos. Chem. Phys., 15, 13453-13473, https://doi.org/10.5194/acp-15-13453-2015, 2015.

Carslaw, K. S., Boucher, O., Spracklen, D. V., Mann, G. W., Rae, J. G. L., Woodward, S., and Kulmala, M.: A review of natural aerosol interactions and feedbacks within the Earth system, Atmos. Chem. Phys., 10, 1701-1737, https://doi.org/10.5194/acp10-1701-2010, 2010.

Chazette, P., Dabas, A., Sanak, J., Lardier, M., and Royer, P.: French airborne lidar measurements for Eyjafjallajökull ash plume survey, Atmos. Chem. Phys., 12, 7059-7072, https://doi.org/10.5194/acp-12-7059-2012, 2012.

Clarke, A., McNaughton, C., Kapustin, V., Shinozuka, Y., Howell, S., Dibb, J., Zhou, J., Anderson, B., Brekhovskikh, 
V., Turner, H., and Pinkerton, M.: Biomass Burning and Pollution Aerosol over North America: Organic Components and their influence on Spectral Optical Properties and Humidification Response, J. Geophys. Res., 112, D12S18, https://doi.org/10.1029/2006JD007777, 2007.

Collaud Coen, M., Weingartner, E., Schaub, D., Hueglin, C., Corrigan, C., Henning, S., Schwikowski, M., and Baltensperger, U.: Saharan dust events at the Jungfraujoch: detection by wavelength dependence of the single scattering albedo and first climatology analysis, Atmos. Chem. Phys., 4, 2465-2480, https://doi.org/10.5194/acp-4-2465-2004, 2004.

Collis, R. T. H. and Russell, P. B.: Lidar measurement of particles and gases by elastic backscattering and differential absorption in Laser Monitoring of the Atmosphere, edited by: Hinkley, E. D., Springler-Verlag, New York, 71-152, 1976.

Deroubaix, A., Flamant, C., Menut, L., Siour, G., Mailler, S., Turquety, S., Briant, R., Khvorostyanov, D., and Crumeyrolle, S.: Interactions of atmospheric gases and aerosols with the monsoon dynamics over the Sudano-Guinean region during AMMA, Atmos. Chem. Phys., 18, 445-465, https://doi.org/10.5194/acp-18445-2018, 2018.

Ek, M. B., Mitchell, K. E., Lin, Y., Rogers, E., Grunmann, P., Koren, V., Gayno, G., and Tarpley, J. D.: Implementation of Noah land surface model advances in the National Centers for Environmental Prediction operational mesoscale Eta model, J. Geophys. Res.-Atmos., 108, 8851, https://doi.org/10.1029/2002JD003296, 2003.

Evan, A. T., Vimont, D. J., Heidinger, A. K., Kossin, J. P., and Bennartz, R.: The role of aerosols in the evolution of tropical North Atlantic Ocean temperature anomalies, Science, 324, 778-781, 2009.

Flamant C., Knippertz, P., Fink, A. H., Akpo, A., Brooks, B., Chiu, C. J., Coe, H., Danuor, S., Evans, M., Jegede, O., Kalthoff, N., Konaré, A., Liousse, C., Lohou, F., Mari, C., Schlager, H., Schwarzenboeck, A., Adler, B., Amekudzi, L., Aryee, J., Ayoola, M., Batenburg, A. M., Bessardon, G., Borrmann, S., Brito, J., Bower, K., Burnet, F., Catoire, V., Colomb, A., Denjean, C., Fosu-Amankwah, K., Hill, P. G., Lee, J., Lothon, M., Maranan, M., Marsham, J., Meynadier, R., Ngamini, J.-B., Rosenberg, P., Sauer, D., Smith, V., Stratmann, G., Taylor, J. W., Voigt, C., and Yoboué, V.: The Dynamics-Aerosol-ChemistryCloud Interactions in West Africa field campaign: Overview and research highlights, B. Am. Meteorol. Soc., 99, 83-104, https://doi.org/10.1175/BAMS-D-16-0256.1, 2018.

Flemming, J., Huijnen, V., Arteta, J., Bechtold, P., Beljaars, A., Blechschmidt, A.-M., Diamantakis, M., Engelen, R. J., Gaudel, A., Inness, A., Jones, L., Josse, B., Katragkou, E., Marecal, V., Peuch, V.-H., Richter, A., Schultz, M. G., Stein, O., and Tsikerdekis, A.: Tropospheric chemistry in the Integrated Forecasting System of ECMWF, Geosci. Model Dev., 8, 975-1003, https://doi.org/10.5194/gmd-8-975-2015, 2015.

Haywood, J. and Boucher, O.: Estimates of the direct and indirect radiative forcing due to tropospheric aerosols: A review, Rev. Geophys., 38, 513-543, 2000.

Hong, S. and Lim, J.: The WRF single-moment 6-class microphysics scheme (WSM6), Journal of the Korean Meteorological Society, 42, 129-151, 2006.
Hong, S.-Y., Noh, Y., and Dudhia, J.: A new vertical diffusion package with an explicit treatment of entrainment processes, Mon. Weather Rev., 134, 2318-2341, 2006.

Huang, J., Zhang, C., and Prospero, J. M.: Large-scale effect of aerosols on precipitation in the West African Monsoon region, Q. J. Roy. Meteor. Soc., 135, 581-594, https://doi.org/10.1002/qj.391, 2009.

Jaffe, D. A. and Wigder, N. L.: Ozone production from wildfires: A critical review, Atmos. Environ., 51, 1-10, 2012.

Kalthoff, N., Lohou, F., Brooks, B., Jegede, G., Adler, B., Babic, K., Dione, C., Ajao, A., Amekudzi, L. K., Aryee, J. N. A., Ayoola, M., Bessardon, G., Danuor, S. K., Handwerker, J., Kohler, M., Lothon, M., Pedruzo-Bagazgoitia, X., Smith, V., Sunmonu, L., Wieser, A., Fink, A. H., and Knippertz, P.: An overview of the diurnal cycle of the atmospheric boundary layer during the West African monsoon season: results from the 2016 observational campaign, Atmos. Chem. Phys., 18, 2913-2928, https://doi.org/10.5194/acp-18-2913-2018, 2018.

Kim, P. S., Jacob, D. J., Liu, X., Warner, J. X., Yang, K., Chance, K., Thouret, V., and Nedelec, P.: Global ozone-CO correlations from OMI and AIRS: constraints on tropospheric ozone sources, Atmos. Chem. Phys., 13, 9321-9335, https://doi.org/10.5194/acp13-9321-2013, 2013.

King, M. D., Kaufman, Y. J., Menzel, W. P., and Tanré, D.: Remotesensing of cloud, aerosol, and water-vapor properties from the Moderate Resolution Imaging Spectrometer (MODIS), IEEE T. Geosci. Remote Sens., 30, 2-27, 1992.

Kirchstetter, T. W., Novakov, T., and Hobbs, P. V.: Evidence that the spectral dependence of light absorption by aerosols is affected by organic carbon, J. Geophys. Res., 109, D21208, https://doi.org/10.1029/2004JD004999, 2004.

Knippertz, P., Evans, M., Field, P. R., Fink, A. H., Liousse, C., and Marsham, J. H.: The possible role of local air pollution in climate change in West Africa, Nat. Clim. Chang., 5, 815-822, https://doi.org/10.1038/NCLIMATE2727, 2015a.

Knippertz, P., Coe, H., Chiu, C., Evans, M. J., Fink, A. H., Kalthoff, N., Liousse, C., Mari, C., Allan, R., Brooks B., Danour, S., Flamant, C., Jegede, O. O., Lohou, F., and Marsham, J. H.: The DACCIWA project: Dynamics-aerosol-chemistry-cloud interactions in West Africa, B. Am. Meteorol. Soc., 96, 1451-1460, $2015 b$.

Knippertz, P., Fink, A. H., Deroubaix, A., Morris, E., Tocquer, F., Evans, M. J., Flamant, C., Gaetani, M., Lavaysse, C., Mari, C., Marsham, J. H., Meynadier, R., Affo-Dogo, A., Bahaga, T., Brosse, F., Deetz, K., Guebsi, R., Latifou, I., Maranan, M., Rosenberg, P. D., and Schlueter, A.: A meteorological and chemical overview of the DACCIWA field campaign in West Africa in June-July 2016, Atmos. Chem. Phys., 17, 10893-10918, https://doi.org/10.5194/acp-17-10893-2017, 2017.

Lelieveld J., Evans, J. S., Fnais, M., Giannadaki, D., and Pozzer, A.: The contribution of outdoor air pollution sources to premature mortality on a global scale, Nature, 525, 367-371, 2015.

Liousse, C., Assamoi, E., Criqui, E. P., Granier, C., and Rosset, R.: Explosive growth in African combustion emissions from 2005 to 2030, Environ. Res. Lett., 9, 35003, https://doi.org//10.1088/1748-9326/9/3/035003, 2014. 
Lothon, M., Said, F., Lohou, F., and Campistron, B.: Observation of the diurnal cycle in the low troposphere of West Africa, Mon. Weather Rev., 136, 3477-3500, 2008.

Mailler, S., Menut, L., di Sarra, A. G., Becagli, S., Di Iorio, T., Bessagnet, B., Briant, R., Formenti, P., Doussin, J.-F., Gómez-Amo, J. L., Mallet, M., Rea, G., Siour, G., Sferlazzo, D. M., Traversi, R., Udisti, R., and Turquety, S.: On the radiative impact of aerosols on photolysis rates: comparison of simulations and observations in the Lampedusa island during the ChArMEx/ADRIMED campaign, Atmos. Chem. Phys., 16, 1219-1244, https://doi.org/10.5194/acp-16-1219-2016, 2016.

Mailler, S., Menut, L., Khvorostyanov, D., Valari, M., Couvidat, F., Siour, G., Turquety, S., Briant, R., Tuccella, P., Bessagnet, B., Colette, A., Létinois, L., Markakis, K., and Meleux, F.: CHIMERE-2017: from urban to hemispheric chemistrytransport modeling, Geosci. Model Dev., 10, 2397-2423, https://doi.org/10.5194/gmd-10-2397-2017, 2017.

Massoli, P., Kebabian, P. L., Onasch, T. B., Hills, F. B., and Freedman, A.: Aerosol Light Extinction Measurements by Cavity Attenuated Phase Shift (CAPS) Spectroscopy: Laboratory Validation and Field Deployment of a Compact Aerosol Particle Extinction Monitor, Aerosol Sci. Tech., 44, 428-435, https://doi.org/10.1080/02786821003716599, 2010.

Menut, L., Flamant, C., Turquety, S., Deroubaix, A., Chazette, P., and Meynadier, R.: Impact of biomass burning on pollutant surface concentrations in megacities of the Gulf of Guinea, Atmos. Chem. Phys., 18, 2687-2707, https://doi.org/10.5194/acp18-2687-2018, 2018.

Mlawer, E. J., Taubman, S. J., Brown, P. D., Iacono, M. J., and Clough, S. A.: Radiative transfer for inhomogeneous atmospheres: RRTM, a validated correlated-k model for the longwave, J. Geophys. Res., 102, 16663-16682, 1997.

Müller, T., Nowak, A., Wiedensohler, A., Sheridan, P., Laborde, M., Covert, D. S., Marinoni, A., Imre, K., Henzing, B., Roger, J.-C., Martins dos Santos, S., Wilhelm, R., Wang, Y.-Q., and de Leeuw, G.: Angular Illumination and Truncation of Three Different Integrating Nephelometers: Implications for Empirical, Size-Based Corrections, Aerosol Sci. Tech., 43, 581-586, 2009.

Müller, T., Henzing, J. S., de Leeuw, G., Wiedensohler, A., Alastuey, A., Angelov, H., Bizjak, M., Collaud Coen, M., Engström, J. E., Gruening, C., Hillamo, R., Hoffer, A., Imre, K., Ivanow, P., Jennings, G., Sun, J. Y., Kalivitis, N., Karlsson, H., Komppula, M., Laj, P., Li, S.-M., Lunder, C., Marinoni, A., Martins dos Santos, S., Moerman, M., Nowak, A., Ogren, J. A., Petzold, A., Pichon, J. M., Rodriquez, S., Sharma, S., Sheridan, P. J., Teinilä, K., Tuch, T., Viana, M., Virkkula, A., Weingartner, E., Wilhelm, R., and Wang, Y. Q.: Characterization and intercomparison of aerosol absorption photometers: result of two intercomparison workshops, Atmos. Meas. Tech., 4, 245-268, https://doi.org/10.5194/amt-4-245-2011, 2011.

Parker, D. J., Burton, R. R., Diongue-Niang, A., Ellis, R. J., Felton, M. A., Taylor, C. M., Thorncroft, C. D., Bessemoulin, P., and Tompkins, A.: The diurnal cycle of the West African Monsoon circulation, Q. J. Roy. Meteor. Soc., 131, 2839-2860, 2005.

Parker, D. J., Kassimou, A., Orji, B. N., Osika, D. P., Hamza, I., Diop-Kane, M., Fink, A., Galvin, J., Guichard, F., Lamptey, B. L., Hamidou, H., van der Linden, R., Redl, R., Lebel, T., and Tubbs, C.: Local Weather, in: Meteorology of Tropical West Africa: The Forecasters' Handbook, edited by: Parker, D. J. and Diop-Kane, M., John Wiley \& Sons, Ltd, Chichester, UK, https://doi.org/10.1002/9781118391297.ch4, 2017.

Remer, L. A., Kaufman, Y. J., Tanré, D., Mattoo, S., Chu, D. A., Martins, J. V., Li, R.-R., Ichoku, C., Levy, R. C., Kleidman, R. G., Eck, T. F., Vermote, E., and Holben, B. N.: The MODIS Aerosol Algorithm, Products, and Validation, J. Atmos. Sci., 62, 947-973, https://doi.org/10.1175/JAS3385.1, 2005.

Russell, P. B., Bergstrom, R. W., Shinozuka, Y., Clarke, A. D., DeCarlo, P. F., Jimenez, J. L., Livingston, J. M., Redemann, J., Dubovik, O., and Strawa, A.: Absorption Angstrom Exponent in AERONET and related data as an indicator of aerosol composition, Atmos. Chem. Phys., 10, 1155-1169, https://doi.org/10.5194/acp-10-1155-2010, 2010.

Salomonson, V. V., Barnes, W. L. , Maymon, P. W., Montgomery, H. E., and Ostrow, H.: MODIS: Advanced facility instrument for studies of the Earth as a system, IEEE T. Geosci. Remote, 27, 145-153, 1989.

Shamarock, W. C. and Klemp, J. B.: A time-split nonhydrostatic atmospheric model for weather research and forecasting applications, J. Comput. Phys., 227, 3465-3485, 2008.

Shang, X. and Chazette, P.: Interest of a Full-Waveform Flown UV Lidar to Derive Forest Vertical Structures and Aboveground Carbon, Forests, 5, 1454-1480, https://doi.org/10.3390/f5061454, 2014.

Spicer, C. W., Joseph, D. W., and Ollison, W. M.: A Re-Examination of Ambient Air Ozone Monitor Interferences, J. Air Waste Manage., 60, 1353-1364, 2010.

Thiébaux, J., Rogers, E., Wang, E., and Katz, B.: A new high-resolution blended real-time global sea surface temperature analysis, B. Am. Meteorol. Soc., 84, 645-656, https://doi.org/10.1175/BAMS-84-5-645, 2003.

Toledano, C., Cachorro, V. E., Berjon, A., de Frutos, A. M., Sorribas, M., de la Morena, B. A., and Goloub, P.: Aerosol optical depth and Ångström exponent climatology at El Arenosillo AERONET site (Huelva, Spain), Q. J. Roy. Meteor. Soc., 133, 795-807, https://doi.org/10.1002/qj.54, 2007.

Werdell, P. J., Franz, B. A., Bailey, S. W., Feldman, G. C., Boss, E., Brando, V. E., Dowell, M., Hirata, T., Lavender, S. J., Lee, Z., Loisel, H., Maritorena, S., Mélin, F., Moore, T. S., Smyth, T. J., Antoine, D., Devred, E., Hembise Fanton d'Andon, O., and Mangin, A.: Generalized ocean color inversion model for retrieving marine inherent optical properties, Appl. Optics, 52, 2019-2037, 2013.

Winker, D. M., Hunt, W. H., and McGill, M. J.: Initial performance assessment of CALIOP, Geophys. Res. Lett., 34, L19803, https://doi.org/10.1029/2007GL030135, 2007.

World Urbanization Prospects: The 2014 Revision, United Nations, Department of Economic and Social Affairs, Population Division, 2015, ST/ESA/SER.A/366, 517 pp., available at: http://www.un.org/en/development/desa/population/ publications/pdf/urbanization/WUP2011_Report.pdf (last access: 16 August 2018), 2015.

Zhang, Y., Fu, R., Yu, H., Dickinson, R. E., Juarez, R. N., Chin, M., and Wang, H.: A regional climate model study of how biomass burning aerosol impacts land-atmosphere interactions over the Amazon, J. Geophys. Res., 113, D14S15, https://doi.org/10.1029/2007JD009449, 2008.

Zhang, Y., Fu, R., Yu, H., Qian, Y., Dickinson, R., Silva Dias, M. A. F., da Silva Dias, P. L., and Fernandes, K.: Im- 
pact of biomass burning aerosol on the monsoon circulation transition over Amazonia, Geophys. Res. Lett., 36, L10814, https://doi.org/10.1029/2009GL037180, 2009. 